BURDENED BY PROOF:

\title{
HOW THE AUSTRALIAN REFUGEE REVIEW TRIBUNAL HAS FAILED LESBIAN AND GAY ASYLUM SEEKERS
}

\author{
Catherine Dauvergne* and Jenni Millbank ${ }^{* *}$
}

Our argument in this paper is that the evidentiary practices and procedures that have been developed by the Australian Refugee Review 'Tribunal are operating at a routinely low standard. Such practices contribute to decisions that are manifestly unfair and potentially wrong in law. A recent working paper from the Office of the United Nations Jigh Commissioner for Refugees ('the UNHCR') notes that evidentiary questions have been 'Targely ignored in the academic literature.' ${ }^{1}$ Our conclusions are drawn from our delailed study of more than 300 refugee tribunal decisions made in Canada and Australia in response to asylum claims brought by lesbians and gay men. Our overall frame of inquiry in this study considers how the respective tribunals grapple with the issue of identity, the complex cluster of dilemmas around the public/private divide, the inability of many decision-makers to inagine the 'other' who stands before them in these clams, and the way this area of law encodes and reflects homophobic stereotyping. ${ }^{2}$ In developing these conclusions, and in particular in examining the marked differences we found between the Australian and the Canadian decisions, we found that the role played by evidentiary practices of the respective tribunals was vital. This article focuses upon how evidence is dealt with in the Australian Tribunal. The comparative data from our study forms a back drop to the

"Canada Research Chair in Migration Law, Associate Professor, Faculty of Law, Universily of British Columbia. This project was supported by a grant from the University of Sydney Faculty of Law Legal Scholarship Support Fund.

Senior Lecturer, Faculty of Law, University of Sydney. An earlier version of this paper was presented at the Ammesty International Global Human Rights Conference, Sydney, 31 October 2002. Thanks to Tiffany Hambley for her research assistance on this paper, and to Arlie Loughnan and Georgina Perry for research assistance on caxlier aspects of the project. For comments on an earlier draft, our thanks to Mary Crock and another reader.

1 Brian Gorlick, Common Burdens and Standaris: Legal Elenents in Assessing Clams to Refugee Stalus (2002) UNT-ICR Working Paper 68, 2 <www. unhuc.ch> at 5 February 2003.

2 See Jenni Millbank, 'Inagining Otherness: Refugee Clains on the Basis of Sexuality in Canada and Australia' (2002) 26 Melboume University Law Review 144; Catherine Dauvergne and Jenni Millbank, 'Before the High Court: Applicants S396/2002 and S395/2002, a Gay Refugee Couple from Bangladesh' (2003) 25 Sydny Law Review 97. 
analysis in this paper, which is focused specifically on the Australian decisions to date. ${ }^{3}$

We develop our argument first by considering the place of evidence in a refugee determination context. We then look at the range of evidence considered by the Refugee Review Tribunal ('RRT') and discuss the unique and problematic role played by evidence provided by Australia's Department of Foreign Affairs and Trade ('DFAT') and evidence taken from the Spartacus International Gay Guide ('Spartacus'). The following section of the paper moves on from considering what is used as evidence to an analysis of inappropriate uses of evidence in the decision-making process. Inappropriate uses of evidence included: a markedly gender-blind approach to evidence, selective use of available evidence, and an indiscriminate approach to questions of weight and relevance of evidence. We then explore alternative approaches to evidence in a detailed study of decisions on a select group of countries. The final section of the paper outlines a series of recommendations for improving the evidentiary practices of the RRT.

Questions of evidence may nevertheless be second order concerns in refugee claims on the basis of sexual orientation. Even if decision-makers had access to the best available independent evidence and weighed it in the most judicious fashion, lesbians and gay men would still face formidable hurdles in the refugee decision-making process. One of the reasons for writing about evidentiary concerns, however, is that the issues that arise in the use of evidence are both glaring and solvable. Without undertaking fundamental reform or investing considerably more resources, the RRT could do a significantly better job with available evidence. The Canadian Tribunal provides an example of a decision-making process that produces markedly different, and demonstrably fairer, results in a substantially similar setting. The Canadian evidentiary databases are available to Australian decision-makers, as are Canadian lessons about evidentiary procedures such as 'credibility testing'. One of our aims here is to strongly argue the case for better grounded refugee decision-making in Australia. Better evidence and better ways of managing the evidence avalable would make it easier to craft solutions to the problems of flawed reasoning that are at the heart of the dramatic and demonstrable failure by the RRT to grapple with claims on the basis of sexual orientation.

\section{THE PARAMETERS OF OUR COMPARATIVE STUDY}

Since the mid 1990s, it has been accepted in many Western refugee-receiving nations that lesbians and gay men may belong to a 'particular social group't and so are eligible

3 This paper includes qualitative analysis of Australian cases to 31 December 2002.

4 The legal definition of a refugee is a standard one, drawr from the Refugee Convention. Article $1 \mathrm{~A}(2)$ of the Convention defines a refugee as any person who:

owing to well-founded fear of being persecuted for reasons of race, religion, nationality, membership of a particular social group or political opinion, is outside the country of his nationality and is unable or, owing to such fear, is unwilling to avail himself of the protection of that country; or who, not having a nationality and being outside the country of his former habitual residence, is unable or, owing to such fear, is unwilling to return to it.

Convention Relating to the Status of Refugees, opened for signature 28 July 1951, 189 UNTS 150 (entered into force 22 April 1954) as amended by the Protocol Relating to the Stalus of 
refugee claimants if they can demonstrate a well-founded fear of persecution based upon that membership. The elements of decisions are thus deceptively simple: are lesbians and gay men a particular social group in the sending country? ${ }^{6}$ is the person lesbian or gay? Are they, or will they be, in danger of persecution on that basis?

In light of Australia's reputation in refugee law - which is currently dominated by mandatory detention of asylum seekers who have entered without valid visas and the tuming away of boats to non-signatory countries - it is hard to recall that Australia had, until recently, a very positive humanitarian image. Canada and Australia have previously been described as 'Ieading the way' in recognising asylum claims based on sexual orientation. ${ }^{7}$ By the time the United Kingdom ('UK') had even accepted that lesbians and gay men were eligible to apply for refugee status, Australia and Canada had between them evaluated hundreds of claims on the basis of sexual orientation. 8

Refuges, opened for signature 31 January 1967, 606 UNTS 267 (entered into force 4 October 1967) ('the Convention').

5 In Canada, the first case to accept that sexual orientation constitutes an eligible social group was in 1991 (although note this case contained a sharp dissenl): Re $R$ (LWW) [1991] CRDD No 50I (QL), IRB Reference U91-03331 (Rotman, Leistra, 7 October 1991). Several more cases were deciaed at tibunal level before this approach was confirmed at judicial level in obiter: Ward o Attomey-General (Canada) (1993) 2 SCR 689 [78]. Likewise in Australia, the first case was in 1994: RRT Reference N93/00593 (Unueported, Tsamenyi, 25 January 1994) and some years passed (during which cases usually referred to Ward) before this view was judicially confirmed, again in obiter: Applicant A v MIEA (1997) 190 CLR 225. In 1995, the UNHCR accepted that lesbians and gay men can constitute members of a 'particular social group' and be eligible for protection under the terms of the Convertion: Ammesty International, Crimes of Hate, Conspiracy of Silence: Torture cond IL-Treatment Based on Sexual Itentity, 2001, 49 (available ondine at <www.amnesty.org>); see also UNI-ICR, Protectirg Refugees: Questions and Answers (2001) <www.unher.ch at 1 April 2002. Since then a number of European nations, such as Austria, Denmark, Germany, the Netherlands, Finland and Sweden have accepted lesbian and gay asylum seekers as members of a 'particular social group'. Amnesty notes that by 2001 at least 18 countries had granted asylum on the grounds of sexuality-related persecution: Amnesty International, above nn 5 . Note that the European Paxliament ('EP') voted to broaden the draft European Commission Directive on the definition of a refugee. The EP added sexual orientation, gender identity and HIV status as elements of the particular social group category. "The final decision remains with the European Conncil of Ministers, but if passed would cover all 25 member nations; see 'Justice and Home Affairs: European Parliament Backs a Broader Definition of Refugee' European Report (Brussels) 23 October 2002, 472.

6 This step has been undertaken in a very cursory fashion in the Australian cases: see Dauvergne and Millbank, 'Before the High Court', above $n 2$.

7 John Russ, "The Gap Between Asylum Ideals and Domestic Reality: Evaluating Human Rights Conditions for Gay Americans by the United States' Own Progressive Asylum Standards' (1998) 4 UCC Davis Intemational Joumal of Law and Policy 29, 55.

8 For a discussion of the early Canadian case law, see Nicole LaViolette, 'The Immutable Refugee: Sexual Orientation in Canada (AG) v Ward' (1997) 55 University of Toronto Facuity of Law Review 1. On early Australian case law, see Jenni Millbank, 'Fear of Persecution or Just a Queer Feeling? Refugee Status and Sexual Orientation in Australia' (1995) 20 Altemative Law Joumal 261, and Kristen Walker, 'The Importance of Being Out: Sexuality and Refigee Status' (1996) 18 Sydney Law Review 568. For an overview of the social group category and sexuality in the UK, Canada, United States of America ('US), New Zealand and Australia, see Kristen Walker, 'Sexuality and Refugee Status in Australia' (2000) 12 Intemational 
We examined 331 decisions on sextuality-based claims from the refugee tribunals of Australia ('RRT') and Canada (Immigration and Refugee Review Board ('IRB')) focusing on the 6 year period from 1994-2000. ${ }^{9}$ The two countries have similar laws and processes for refugee determination ${ }^{10}$ and both were among the first countries to accept that lesbians and gay men were eligible for Convention protection. Our study intended to evaluate how lesbian and gay asylum seekers were faring after a settled period of claims. We were surprised by the extent of difference that we found Australia was consistently harsher to applicants than Canada, both in the reasoning employed in the decisions and in the trend of outcomes, which had a far lower success rate for both lesbian and gay applicants. One hundred and twenty-seven of the decisions studied were Canadian and 204 were Australian. Considering all claims, 35 per cent of decisions were favourable to the applicant. In Australia, only 22 per cent of claims overall were successful, while in Canada the figure was more than double that, at 54 per cent. In is noteworthy that in the years since our case pool ended, the success xate of applicants in Australia has not increased: in the years 2000-02 it remained at 21.6 per cent. ${ }^{11}$

Lesbian claimants were dramatically under-represented, with only 14 per cent of the Canadian claims and 21 per cent of the Australian claims brought by women. Comparing lesbian claimants in both countries is shocking: in Canada their success rate was ten times that of Australia. In Canada, lesbian claimants actually had a somewhat higher success rate than gay men (69 per cent while gay men had a 52 per cent stccess rate) while in Australia lesbian claimants were overwhelmingly unsuccessful (a mere seven per cent of lesbian claimants succecded, compared to 26 per cent of gay men).

This disparity in outcomes is only partly explained by a different mix of sending countries in the cases considered by the two tribunals. ${ }^{12}$ Where the country of origin was comparable, the same broad trends were still present, with Australia consistently

Joumal of Refugee Law 175 . Note that the UK was comparatively late, with conflicting decisions at administrative level through the mid 90s and judicial acceptance only in 1999: see Walker 'Sexualily and Refugee Status in Australia' 183, n 39; Derek McGhee, 'Persecution and Social Group Status: Homosexual Refugees in the 1990s' (2001) 14 Joumal of Refugee Studites 20.

9 Canadia issued 13 decisions in $1991-93$ period, but it was from 1994 onwards that most claims were heard in a settled post-Wart period of decided eligibility.

10 See Audrey Macklin 'Cross-Border Shopping for Ideas: A Crifical Review of United States, Canadian, and Australian Approaches to Gender-Related Asylum Claims' (1998) 13 Georgetown Immigration. Law Journal 25. The most important distinction is that the refugee determination tibunal in Canada makes the decision at first instance whereas the Anstralian Tribunal conducts a meril review. This distinction is less significant than it seems at first because the acceptance rates at first instance in Australia are very low ( 8 per cent) and a majority of those who are rejected seek a merits review in the RRT. In addition, the RRT is a full merits review and thus the issues are canvassed in a similar way in each tribunal.

11 Based on all available cases on Australian Legal Information Institute ('Austlii') between May 2000 and December 2002.

12 Australia had a higher proportion of cases from Asia, while Canada had more cases from Southern and Central America. 
refusing a far higher proportion of applicants. ${ }^{13}$ We argue that one of the most important reasons for the difference in outcomes in Australia and Canada is the evidentiary practices of the RRT,

It is the evidentiary practices of the tribunals, rather than the courts, that are vital to outcomes as it is in tribunals that the vast majority of cases are finally determined. Very few refugee cases are judicially reviewed by the respective federal courts. ${ }^{14}$ In our pool there were only 12 Federal Court cases in Canada (nine per cent of Canadian cases) and six Federal Court cases in Australia (three per cent of the available cases). ${ }^{15}$ The range of issues dealt with by the courts is narrow because of the nature of judicial review, with courts necessarily deferring to tribunal findings of fact, including findings on the objective likelihood of future persecution based on country conditions. 16 of the handful of cases that were judicially reviewed in our pool, only three were successful in Canada, and none of the Australian claimants ultimately succeeded in the courts. ${ }^{17}$

13 So, for example, in cases concerning Malaysia, where similar country information was utilised, Australia considered six claims and rejected all of them (5 men and 1 woman) while Canada considered two (both from men) and accepted both. See also later discussion of applicants from Iran.

14 The ability to seek judicial review has been continually circumscribed in Australia in recent years, see Mary Crock, 'Making Sense of the Rule of Law: Trends in Judicial Review of Migration Decisions' (2002) 8 immigration Reoiew 9. In Canada, leave must be sought from the Federal Coutt.

15 PIus one successful claim on HIV status: Kuthyar v MIMA [2000] FCA 110.

16 See, eg:

The country information consulted by the RRT suggested that the Iranian authorities do not actively seek out homosexuals and the risk of prosecution for homosexuality is minimal so Iong as the activities are carried out discreetly. This evidence may or mony not be correct. However, it was before the RRT and the RRT formed the view that it was appropriate to rely on it. That essentially is a question for the RRT, being a question of fact and degree as to the relative weight to be given to the assertions by the applicant and the independent country evidence which is referred to in the decision.

Gholoni v MIMA [2001] FCA 1091 [14] (emphasis added). See also $n 182$ below.

7 Guo Ping Gui v MIMA [1998] FCA 1592 (the applicant was successful at first instance, but the decision was overtumed on appeal to a Full Court of the Federal Court): MIMA 0 Gui [1999] FCA 1496. See also MIMA o Guan [2000] FCA 1033 (unsuccessful appeal by Minister). Note that in the June 2001-Maxch 2003 period, outside of our pool, ten applications for judicial review from claims based on sexual orientation went to the Federal Court, of which only one was successful. See Gautan o MIMA [2000] FCA 1367; Khanmieeri o MIMA [2002] FCA 625; Khalili v MIMA [2001] FCA 1404, the appeal to a Full Court of the Federal Court reported as SAAF o MMA [2002] FCA 343; Kabir o MIMA [2001] FCA 968 , and on appeal to a Full Court of the Federal Court: Kabir o MIMA [2002] FCAFC 20; SAAM v MIMA [2002] FCA 444; Nezhadian o MIMA [2001] FCA 1415, and on appeal to a Full Court of the Federal Court reported as WABR $v$ MIMA [2002] FCAFC 124; WAAG $v$ MIMIA [2002] FMCA 191 (successful review by Federal Magistrate on the ground of bias) overtumed on appeal to a Full Court of the Federal Court in MIMIA SBAN [2002] FCAFC 431; NAIO of 2002 v MIMIA [2002] FCA 1075, and on appeal to a FuIl Court of the Federal Court: NAIQ of 2002 o MIMIA [2002] FCAFC 408; NAKX of 2002 V MIMIA [2002] FCA 1488; NAFP o MIMIA [2003] FCA 241. The only appeal upheld was W133/01A [2002] FCA 395. Note that when this case was returned to the Tribunal and reheard by a new nember, the claim was refused on the new ground that the Tribunal did not accept that the applicant was gay (despite finding in the original case that the applicant was gay, but did not have a well- 
The addition of a privative clause to the Migration Act 1958 (Cth) in 2001 further entrenches the primary role of the Tribunal and renders it the final decision in virtually all cases. 18

\section{EVIDENCE IN THE CONTEXT OF REFUGEE DETERMINATIONS}

A refugee determination hearing has little in common with settings where the common law rules about evidence and about what counts as true proof, have been delineated and refined over the past few centuries. In a typical RRT hearing there are only three people in the room: the decision-maker, the claimant and an interpreter. ${ }^{19}$ The claimant tells her story and the Tribunal member decides if she is a refugee. Credibility is often at issue - published reasons suggest that the decision-makers frecuently ondy believe part of the story told, even in positive decisions. ${ }^{20}$ Witnesses are rarely called, and most often the claimant does not have anything 'on paper' to support their story (although they frequently have some type of identity document which supports their claim in part by assisting in establishing their identity). Many of the accepted ways of establishing truth in a legal setting are absent.

In addition, the claimant is by definition from another culture. Refugees have often suffered at the hands of the state, and are sometimes survivors of torture or trauma. Alf of these factors further interfere with the decision-maker's ability to intuit who is telling the truth and who is not. Verbal and non-verbal clues - such as eye contact or consistency in telling the story - are unreliable indicators in this setting. Both the Australian and the Canadian tribunals accept that cross-examination, the recognized common law 'cure' for problematic oral evidence, is inappropriate in refugee hearings because of the vulnerability of the claimant and because the tribunal procedure is not considered to fall within the adversarial model.

Rather than rely on witnesses, documents or cross-examination - rules of evidence which encode our understandings of what we will accept as proof - refugee decisionmakers listen to the story told and translated and then make decisions about credibility

founded fear because he could avoid danger by 'discretely' hiding that fact). An appeal from this latter decision was dismissed by the Federal Magistrates Court: WAIH v MIMIA. [2003] FMCA 40. In a recent article John McMillan argues that Federal Court judges in Australia have exercised 'overly-thorough judicial scrutiny' and in a 'self-styled judicial emphasis on human rights protection' over-reached their powers in immigration decisions: John McMillan, 'Judicial Restraint and Activism in Administrative Law' (2002) 30 Federal Law Review 335, 352 and 354 . This point is demonstrably not borne out in Federal Court decisions on sexual orientation.

18 See Ron Kessels and Arthtr Glass, 'The Privative Clause and Judicial Review' (2002) 1 Intwigration Retriew 10; Simon Evans, 'Protection Visas and Privative Clause Decisions: Hickman and the Migration Act 1958 (Cth)' (2002) 9 Australian Joumal of Administratioe Lazo 49. The application of the privalive clause was recently read down by the High Court in Plaintiff S157/2002 conmonwealth of Australia (2003) 195 ALR 24.

19 This differs from the Canadian hearing format where the claimant is usually represented by a lawyer and a Refugee Hearing Officer, charged with assisting the tribunal, also participates in the hearing. Under the new Canadian rules, the relevant Minister also has a right to participate in refigee determination hearings.

20 For a critique of the Canadian process see Cecile Rousseau et al, 'The Complexity of Determining Refugeehood: A Mulli-Disciplinary Analysis of the Decision-making Process of the Canadian Immigration and Refugee Board: (2002) 15 Journal of Refugee Studies 43. 
largely by comparing that story to other information that they have about the place the story describes. ${ }^{21}$ This other information is known as 'independent evidence' because it is not provided by the claimant. It comes from diverse sources including the international and overseas local press, reports of non-governmental organizations, and government sources. A claimant is more likely to be believed if the story she tells fits within the parameters of the story presented in these other sources. Independent evidence is not, therefore, provided to formally corroborate a claimant's account of events, but rather to provide a context against which a claimant's story can be heard and assessed.

In light of this context, the Office of the UNI-ACR Handbook notes that:

The requirement of evidence should ... not be too strictly applied in view of the difficulty of proof inherent in the special situation in which an applicant for refugee status finds himself. Allowance for such possible lack of evidence does not, however, mean that unsupported statements must necessarily be accepted as true if they are inconsistent with the general account put forward by the applicant. ${ }^{22}$

The Handbook states further,

it is hardly possible for a refugee to 'prove' every part of his case and, indeed, if this were a requirement the majority of refugees would not be recognized. It is therefore frequentily necessary to give the applicant the benefit of the doubt. ${ }^{23}$

Given the complexities of the refugee determination setting, neither the RRT nor the Canadian Tribunal are bound by the formal rules of evidence. ${ }^{24}$ This is essential to the logic of the hearing. Without this proviso, many aspects of claimants' stories, as well as some of the independent information, would not be allowed into the process and the hearings which are often intensely intimate would be halted at the introduction of each new element of proof. The removal of the often very technical strictures of evidence law facilitates the provision of decisions which are 'economical, informal and quick',25

21 Furthermore, while tribunals do administer oaths before hearing the applicant's story, the role which the oath plays is considerably diminished, at least symbolically, in a setting such as the RRT where the form of the Christian oath is simply translated into a variety of languages and the applicant is then asked to read it - without an inquiry into whether oath swearing or affirming is at all culturally or religiously translatable in this simple way. As early as 1744 in Onychmid o Burker 26 ER 15, 31 (Willes LC), the English Court of Appeal impugned the practice of having non-Christians swear Christian oaths:

it would be absurd for him to swear according to the Christian oath, which he does not believe; and therefore, out of necessity, he must be allowed to sweat according to his own notion of an oath.

22 Office of the United Nations High Commissioner for Refugees, Handbook on Procedures and Criteria for Detemining Refugee Status under the 195I Convention and the 1967 Protocol Relating to the Status of Refingees (2nd ed, 1988) 47, [197].

23 Ibid 48, [203].

24. Migration Act 1958 (Ch) s 420(2)(a); Immigration and Refugee Protection Act SC 2001. c 27, s $170(\mathrm{~g})$; which carries on the provision of the Immigration Act RSC 1985 c I-2, s 68(3) which controlled the IRB during the timeframe of our study.

25 Section 420(I) of the Migmation Act 1958 (Cth) states '[ [ ] ] Tre Tribunal, in carrying out its function under this Act, is to pursue the objective of providing a mechanism of review that is fair, just, economical, informal and quick. 
In the RRT, where lawyers are rarely present ${ }^{26}$ adherence to the formal rules of evidence would be completely unworkable.

In both Canada and Australia, the tribunal hearings are considered non-adversarial and have been described as following the inquisitorial model. Despite being, therefore, outside the norms and values of the adversarial system, these tribunal procedures take place within legal contexis where the values and norms of non-adversarial systems are not well known and where if judicial review is sought, the adversarial system comes fully into play. We agree with Justice Michael Kirby that it is not important to classify the tribunal proceedings as inquisitorial, adjudicative, or investigative. ${ }^{27} \mathrm{It}$ is, instead, important to note that the tribunals do not follow central aspects of the adversarial system. While this is intended to benefit the claimants and undeniably has important benefits to offer, the adversarial system also offers certain protections to individuals who engage it, some of which are provided by the rules of evidence.

The absence of formal rules of evidence is in keeping with the administrative tribunal model of decision-making more broadly. This criterion is common for administrative tribunals. The ideology of tribunal justice suggests that many decisions are better made without the technicalities of the law and that the needs of tribunal clients are better met in informal settings. The refugee tribunal occupies an awkward place in this picture: it is at once the tribunal setting where formal rules of evidence are the least likely to fit the situation, and at the same time the place where the power imbalance between client and decision-maker is the greatest and thus complete informality leads to greatest vulnerability.

While the RRT is not bound by formal rules of evidence, it is also not required to ignore them. The same section which frees it from this stricture also mandates that the Tribunal act according to 'substantial justice and the merits of the case'..$^{28}$ A number of provisions of the RRT's mandate give it powers to deal with evidence in formal ways which resemble common law evidence provisions. ${ }^{29}$ It also has powers to gather evidence which are in keeping with the non-adversarial logic of the Tribunal. ${ }^{30}$ The ribunal is required to provide written reasons which set out 'findings on material questions of fact' and which refer to the 'evidence' or other material on which those

26 Applicants in the RRT are not entitled to be 'represented' by any other person under $s 427(6)$ of the Migration Act 1951 (Cth). While lawyers may attend RRT hearing to 'assist', they are only allowed to contribute to the discussion at the presiding tribunal member's discretion. See Refugee Review Tribunal, General Practice Directions (2003) 14, [21], online at chttp:/ /www.rrt.gov.au/practice.htm> at 23 July 2003. While claimants may be legally assisted in preparing their cases, legal aid is limited to appeal matters, and only available if there is a legal question over which jucticial opinion is not settled: see, for example, Legal Aid Commission of NSW, Givil Lazu (Conntonwealth): Gridelines (2002) <http:/ / www.legalaid.nsw.gov.au/lac/lac.nsf/pages/covguide> at 16 December 2002. Re MIMA; Ex Patte Epeabaka (2001) 206 CLR 128, 150, [63].

Migration Act 1958 (Cth) s $420(2)$ (b).

29 For example, the RRT has the power to take evidence on oath or affirmation, to summons persons to give evidence, Migration Act 1958 (Cth) s 427. It carl also authorize that evidence be taken elsewhere on its behalf, $s 428$; take evidence by telephone or using other means of communication, $\$ 429 \mathrm{~A}$; and penalize those who do not comply with its evidentiary requests, ss 433 and 434 .

30 Migration Act 1958 (CLi) ss $424,424 B, 426$. 
findings are based. ${ }^{31}$ All of these factors suggest that the Tribunal's ability to dispense with the techricalities of the rules of evidence ought not be read as a capacity to dispense with the principles of evidence that underlie these specific rules. The 'relaxation' of the rules of evidence is 'not an invitation to palm tree justice. ${ }^{132}$

Conventionally, evidentiary requirements are most stringent in those settings where the consequences for an individual are most serious, such as a loss of liberty. ${ }^{33}$ White this generalisation applies to forums that have not ousted evidentiary provisions, the logic of this guiding principle remains relevant: in the case of a refugee hearing, the consequences for the individual are very serious, comparable to or in excess of a potential loss of liberty. The tribunal values of speed, economy and informality were encoded to best serve those with a stake in the decisions to be delivered, and were never intended to be separated from the values of fairness and justice.

In the absence of formal rules for dealing with evidence, the practice of the RRT has evolved in a highly inconsistent manner. This inconsistency, and the problems it leads to in terms of weight and relevance of evidence, depart not only from the technicalities of evidence law bul also from its central values. Our argument is that the intent of the legislation was never to discard the spirit of the law of evidence and the core commitment to faimess that il represents.

The office of the UNHRC has recently argued that:

In view of the particular nature of the refugee situation and the vulnerability of some asylum seekers, the decision-maker must share the duty to ascertain and evaluate all relevant lacts ... Seeling and referring to [country] information should be considered an essential undertaking by the decision-maker towards satisfying the shared responsibility of the burden of proof. 34

31 Migration Act 1958 (Cth) s $430(1)$.

32 Cho r MIMA (1998) 55 ALD 487, 501 (Madowick D). His Honour continues

in $R$ o War Pensions Entitlement Appeal Tribunal; Ex parte Bott (1933) 50 CLR 228 ; at 256, Evatt I said: 'Some stress has been laid by the present respondents upon the provision that the tribunal is not, in the hearing of appeals, "bound by any rules of evidence". Neither it is. But this does not mean that all rules of evidence may be ignored as of no account. After all, they represent the attempt made, through many generations, to evolve a method of inguiry best calculated to prevent error and elicit truth. No tribural can, without grave danger of injustice, set them on one side and resort to methods of inquiry which necessarily advantage one party and necessarily disadvantage the opposing party. In other words, although rules of evidence, as such, do not bind, every attempt musl be made to administer "substantial justice": at: 501.

Justice Madgwick concludes with respect to the RRT that,

[i]f there is no licence for an ultmate abandonment of any logical connection between the material and the decision, there is no better reason to assume that the Act was intended to authorise the partial or intermediate abandonment of such connections. It is with that concept, rather than with a merely gualitative assessment of the degree of acceptability of a judgment rationally available to the Tribunal, that I have been concerned: at 501-2.

33 Colin Tapper, Cross and Tapper on Evidence (9th ed, 1999) 18-19.

34. Gorlick, above n 1, 5 (emphasis added). 
In the RRT there is no duty of procedural faimess in the conduct of the hearing itself, and although decision makers have the power to make inquires of the applicant, they do not have a duty to do so..$^{35}$

In the next section, we canvass the role of independent evidence in decisions, consider the types of independent evidence used in RRT decisions and contrast these sources with those used in the Canadian Tribunal.

\section{THE PLACE OF INDEPENDENT EVIDENCE}

'Independent country information' is used by tribunals as evidence of the general situation in a country, against which the applicant's particular claims are assessed. Such information is typically drawn from press reports, human rights organisations and government sources. Decision-makers use these 'independent' sources of generalised country information to weigh against the applicant's specific claims to determine if they are credible. They also use such information to determine if a likelihood of future persecution exists. ${ }^{36}$ Such evidence can therefore have an enormous impact both on whether the applicant's claims are believed about the past, and on whether they are seen as in danger of persecution in the future.

The importance of independent evidence is heightened by the perception that refugee claimants tell lies. ${ }^{37}$ It is impossible to say how prevalent this is, but there are clearly a number of incentives to try to bring oneself within the refugee definition. For people whose lives in their homelands are destitute or dangerous, and who do not qualify for the increasingly globally competitive immigration program, ${ }^{38}$ refugee status is the only formal way to be allowed to remain in Australia or another prosperous nation. For people who have been persecuted by their home states, harassed by police, or ignored when they sought assistance, Iying to those in authority may seem a necessity. Telling a lie, or even many lies, does not mean that someone is not a refugee. It does, however, complicate the process of weighing evidence, listening to a claimant's story, and imagining what is likely to happen in the future - the onerous task of a refugee decision-maker.

It is important to recall that the standard of proof that an applicant must meet in the Tribunal is not the civil standard of balance of probabilities, but a standard unique to the refugee setting: that of a 'real chance' of persecution. The High Court has defined

35 See Migration Act 1958 (Cth) s 424(2).

36 The central inquiry regarding persecution is necessarily a future looking one, in which past persecution is to be treated as only one indicator: Chan Yee Kin v MIEA (1989) 169 CLR 379.

37 This perception was at the core of a bias claims concerning an RRT member who had published on his personal website his view that refugee clamants often 'lie through their teeth': in MIMA o Epeabaka [1999] FCA 1 [13]; see also Re MIMA; Ex parte Epeabaka (2001) 206 CLR 128

38 Australia, like Canada, considers that its immigration program ought to be selecting the best and the brightest from around the world to bolster Austalia's economy. Since 1996, Australia has granted economic category migration priority over family category migration, and recent changes have been directed towards making recruiting wealthy, skilled, English speaking migranls easier. See Philip Ruddock, 'Opening Speech' (Speech delivered at the Migration: Benetiting Austalia Conference, 7 May 2002) $<$ http:/ www.minister.immi.gov.au/media/transcripts/transcripts02/migration _conf.him> at 18 December 2002. 
this standard as one that is not remote or insubstantial but which may be well below 50 per cent. ${ }^{39}$

Looking at the use of independent evidence broadly across both countries, our data show that the most commonly used information sources were international commercial and mainstream media reports which are referred to in 36 per cent of cases, ${ }^{40}$ international human rights organisations such as Amnesty International and Human Rights Watch whose reports were referred to in 29 per cent of cases, United States State Department country reports which were used in 28 per cent, published academic papers which were referred to in 18 per cent, and reports prepared by queer activist groups used in $14 \mathrm{per}$ cent of cases. Usage of these sources was roughly comparable in the two tribunals, although the Canadian Tribunal used reports of queer activist groups comparatively more often and the Australian decision-makers relied more often on the international press. Looking beyond these sources, however, comparability breaks down. The RRT referred to cables sent by DFAT in 48 per cent of cases. The Canadian equivalent was never used. The Australian Tribunal also referred to Spartacus in 24 per cent of cases ${ }^{41}$ This guide was never cited in Canada. Both DFAT and Spartacus were highly problematic sources of evidence and we address them in specific case studies below.

Country information is of major significance in all refugee cases, and many of the points that we make about the quality of evidence would be equally applicable across the whole case range in the RRT. However, there are also issues of accessibility and interpretation that are particular to claims on the basis of sexual orientation. Nicole LaViolette notes that, 'in many countries very little information is available on human rights violations against sexual minorities. ${ }^{42}$ In persecutory regimes, local lesbian and gay organisations, if they exist at all, may have considerable difficulty in marshalling, or making public, evidence of persecution. The International Gay and Lesbian Human Rights Commission (IGLHRC) country information pack on Iran quotes numerous sources on the enormous difficulty of amassing documentation on sexuality related abuses in that country. ${ }^{43}$ Homan, an Iranian gay and lesbian refugee group has made

39 Chan Yin Kin v MIEA (1989) 169 CLR 379; Applicant A v MIEA (1997) 190 CLR 225.

40 One hundred and nimeteen of 331 cases. Of these, Reuters is the source most often cited, in 19 of the cases.

41 Forty $\rightarrow$ nine of 204 cases. The complete list of sources we coded for is: academic sources, AIDS activist groups, queer activist groups, human rights civic organizations, local (Australian or Canadian) press, local queer press, intemational gay and lesbian press, international mainstream commercial press, DFAI", Canadian Immigration and Refugee Board Documentation Centre responses to specific information requests, other government sources, consular sources, courtry of origin press, country of origin legal sources, internet, Lonely Planet guidebooks, Reuters, medical souces, Spartacus, Third Pink Book, US State Department country reports, UN Sources, Encyclopedin of Homosexuality and religious or church soturces.

42 Nicole LaViolette, 'Proving a Well-Founded Fear' in Sydney Levy (ed), Asyllum Based on Sexual Orientation: A Resolire Guide (1996).

43 See, eg, 'Th is particularly difficult to prove a well-founded fear of persecution [in cases of sexuality] because there is relatively little documentation of anti-gay action by govemments.' Suzanne Goldberg, Lambda Legal Defense and Education Fund, quoted in Keith Donoghue, 'INS Showing New Sympathy for Gay Refugees', The Recorder, 25 October 1995,11 . This may even extend to obtaining information from expatiates: 
this point even of human rights abuses that to receiving countries would seem the most obviously documentable, such as executions:

It is notoriously difficuit to be certain about the exact number of gays and lesbians killed because some executions take place in secret and the relatives of those killed often try to cover up the tue reason due to the strong social stigma associated with homosexuality. 44

Major international human rights Non-Governmental Organizations ('NGOs'), which are not under threat locally and which have far greater access to resources to document and publicise persecution, such as Amnesty International and Human Rights Watch, did not include lesbians and gay men in the ambit of their work until recent years. ${ }^{45}$ Hence these organisations did not even begin to seek information on experiences of homophobic persecution unlil the mid-1990s - the point at which Australia and Canada were dealing with the first influx of claims. In 2001 Amnesty International affirmed that difficulty in gathering evidence continues to be an issue, as '[p]patterns of torture and other abuses facing lesbians and gay men are not well documented in most countries: 46

In some of the early Canadian cases on sexuality, a lack of information on human rights abuses was interpreted by the tribunals as evidence that there were no human rights abuses, ${ }^{47}$ however later cases did not continue with that presumption. The Australian Tribunal has more frequently, and more recently, interpreted a lack of evidence as evidence of a lack of persecution. In several cases concerning China, the applicant's evidence of personal experience of persecution was weighed against country information that established only a pervasive lack of evidence of sexuality based persecution (rather than a lack of persecution) and the applicant's case was dismissed or disbelieved on this basis ${ }^{48}$

Arman will not disclose his last name or his hometown. 'Even abroad, gay Iranians can't cease being frightened for themselves and their lamilies back in Iran,' explains Arman. 'Now this terror is a part of our body and psyche.'

Daniela Danna, 'Punishable by Death', The Advocate [no date], 60. Both foregoing sources are in the IGLIHRC's Current Lipdate Packet: Iran, on file with authors. The role of the IGLHRC in gathering country information is discussed below, in the section entitled 'An Alternative Approach to Independent Evidence'.

44 Peter Tatchell, 'The New Dark Ages'. Homan, Issues 10 and 11, June 1996, 15. Reproduced in the IGLHRC's Country Packet: Irant \#2.

45 LaViolette, 'Proving a Well-Founded Fear', above n 42, 5. LaViolette notes that Amnesty only recognised that lesbians and gay men were prisoners of conscience in 1991 and issued ils first teport on human rights abuses based on sexuality in 1994. Human Rights Watch first adopted a sta tement including lesbians and gay men within its mandate in 1994.

46 Amnesty International, Crimes of Hate above n 5, 49. This also applies to the receiving countries. Evidence in one Australian case on Nepal noted that 'the US State Department [human rights report on Nepai] makes no relerence to homosexuality as it is outside the pirrameters of htimum rights reports.' Gantamt v MIMA [2000] FCA 1367 (emphasis added).

47 See LaViolette, 'Proving a Well-Founded Fear' above $n$ 42, 7.

48 See, eg, a case where the decision-maker acknowledged twice that none of the country information referred to concerned lesbians but then concluded,

[t] here have been no leports of lesbian women being harassed by the authorities or mistreated by society in general, whether in Shanghai, or indeed, anywhere else in China. ... The view I take of the evidence, as reviewed above, is that lesbian women do not face serious difficulties and discrimination in Clina today, even if they are Found out.

RRT Reference N98/21640 (Unreported, Klintworth, 21 December 1998). 
Peter Billings argues that:

Without adequate information, those officials who examine and adjudicate on asylum applications will find it difficult to respond expeditiously and consistently to the asylum. applications they receive, and applicants will lack the necessary tools to provide objective evidence in support of their subjective fear. Gathering together publicly available and verifiable sources of information ... is fundamental to safeguarding a meaningful right to petition for asylum. Alluring as the use of information databases may be to those who press for fairer and expeditious determination procedures, the seductive air of electronically accessible county reports should not be deemed the panacea for all evidentiary problems which can plague asylum applications. Modern communications technology has largely eradicated the problems of obtaining information [on genera] county conditions], creating a new challenge in identifying what is relevant to the claim, and what may reasonably be relied upon as credible and atthoritative by the asylum officer or government. 49

The Canadian Tribunal spends around half a million dollars per annum on 'information', but the Australian Tribunal does not provide a breakdown of such expenditure and the figures available in each tribunal's annual reports are not directly comparable ${ }^{50}$ Visits to both tribunals and their libraries make it apparent that the Canadian Tribunal is spending more money on documentation, although this may be a function of its significantly greater caseload.

Generally speaking, the Canadian process is more open and more likely to rely on information generated by organisations with a specific expertise in the human rights of lesbians and gay men. The Canadian 'Tribunal's Documentation Centre has developed an international expertise in gathering independent information for use in refugee decision-making. The Documentation Centre has branches across the country and produces country information packages for its own decision-makers which are made available to others around the world, including Australia. ${ }^{51}$ The resources of the Documentation Centre are available to tribunal staff and decision-makers, to refugee claimants and their legal representatives, and to members of the public.

The Australian Tribunal has a staff section devoted to gathering country information and also a library. It is significant, however, that this information is not available to claimants or their advisors. While decision-makers are required to provide claimants with an opportunity to comment on adverse information that may be used in assessing their claims, claimants do not necessarily receive such information in advance of the hearing, and cannot use the resources of the Tribunal in building their

49 Peter Billings, 'A Comparative Analysis of Administrative and Adjudicative Systems for Determining Asylum Claims' (2000) 52 Adninistrative Law Review 253, 299 (emphasis in original).

50 The RRT's ordinary expenses totalled $\$ 19.1$ million AUD for 2001-02. For 2002-03, the budget of the Canadian Refugee Protection Division (this division is the successor to the Convention Refugee Determination Division which is the relevant division of the IRB for our study) is $\$ 62.6$ million Canadian dollars. See Commonwealth of Australia, Refigee Revie'c Tribunal Anmual Report 2000-2001 (2001) 41; Immigration and Refugee Board, 20022003 Estimates (2002) Pt III. While the RRT decides around 7000 cases per year the IRB decides 40000 . The amount spent per case is roughily similar. The estimated cost per claim in Canada is \$2590 (\$2957 AUD), while there is a \$2400 AUD per application finalised commitment in Australia.

51 Interview wilh Mark Mantle, Sydney, RRT Sydney, Head of Country Juformation Section, (19 February 2002). 
own case. The requirement that adverse information be put to an applicant does not mean that the applicant will necessarily receive a copy of the documents in question. The practice of directing an applicant's attention to evidence adverse to theix claim orally during the hearing was implicitly approved by the Migh Court of Australia in Muin. ${ }^{52}$ It is important to note that the procedural fairness mechanisms in place since 1998, requiring applicants to be provided with particulars of each specific piece of adverse evidence ${ }^{53}$ do not, in fact, assist the vast majority of the clamants we discuss in this article. In most the cases from our pool, it was not particular evidence but generic information about country conditions that was adverse to the claimant's case and held to defeat it.

In addition to openness to the public, the Canadian Tribunal was also more open to our inquiries about their information gathering. Both tribunals produce specific responses to decision-maker's' requests for information. The Canadian Tribunal offered to share these documents with us. ${ }^{4}$ The Australian Tribunal follows a similar practice in that much of the work of the country information research section is driven by specific requests from decision-makers. However, the RRT' was not willing to share with us either example responses to requests or responses to requests specifically relating to cases in our database.

The inaccessibility of independent evidence used by the RRT dearly has the potential to disadvantage claimants. It is an obstacle both to those working to build a file of documentation in support of their claim generally and to applicants attempting to counter negative conclusions based on documentation they have not seen. As the RRT provides review of negative decisions, a claimant is always in the position of arguing against the negative conclusions in their file - and the documents which ostensibly support such conclusions - from the outset.

In addition to these differences in the role and accessibility of independent information in the Australian process, our analysis of the sources used as independent evidence suggest problems in each of the areas where RRT usage is significantly different from practice in the Canadian Tribunal. We turn now to a detailed consideration of the two sources of information that were uniquely prevalent in the RRT: DFAT cables and. Spartacus, In the later section regarding the question of best evidence we take up the other significant variation from Canadian practice: the Australian preference for evidence from sources that have no specific expertise in, or connection with, lesbian and gay issues.

52 Muin o Refugee Review Tribunat; Lie v Refugee Review Tribunal (2002) 190 ALR 601. See, eg 364, [137] (Gleeson C). In the case of Mr Muin, Gleeson CJ, and Gaudron, Mctiugh and Kirby JJ held that this was not done with sufficient specificity.

53 Migration Act 1958 (Cth) 5424 A

54 The Canadian Research Information Requests ('RIRs') are typically one to two singlespaced pages long and include sections on references and also attachments. The information requested ranges from general (eg 'Tanzania: Treatment of homosexuals particularly in the cily of Dar-es-Salaam, TZA32243, E') to specific (eg 'Update to EGY20206.E of 24 March 1995 on the treatment of homosexuals; whether the teatment of a Jewish homosexual would be different; and whether there are services available for persons who are HIV positive, April 1995 to Jaruary 1999; EGY31079.E'). A number of: example RIRs provided to us in 2000 are in our Sydney files. 


\section{DFAT: A question of independence}

The Australian Tribunal used reports solicited from DFAT as an authoritative source of 'independent' evidence about country conditions in almost half of the cases in our pool. ${ }^{55}$ The independence as well as the quality of this information was a significant concern, as its use had a clear impact on the outcomes of cases.

Under the strong version of the separation of powers doctrine which is vital to Australian constitutional arrangements, the RRT is part of the executive branch of government despite its role as an unbiased and impartial decision-making body. This may be part of the explanation for its reliance on DFAT information: the information is generated by the executive itself. There is not theoretically an adversary in the refugee decision-making process, and therefore using government generated information does not, at a theoretical level, create any particular problems. On the other hand, as the present Australian government has demonstrated considerable hostility towards onshore asylum seekers there may be reasons to believe that evidence it generates will not be unbiased. ${ }^{56}$ The quasi-judicial rather than executive status of tribunals in the Canadian setting may provide part of the explanation why the Canadian Tribunal does not rely on similar information generated on request by Canadian government officials.

DFAT evidence was usually provided in the form of a short cable. Any given decision might refer to a number of cables spanuing several years. DFA'T cables were usually expressed as generalised statements about 'the situation' for 'homosexuals' in a given country. DFAT evidence often did not name the original source or authority, but would refer to a 'local lawyer', 'diplomat', or 'expert' as the basis for their claims. ${ }^{57}$ The level of generality in DFAT cables was at times breathtaking, for example, '[t]he level of discrimination against homosexuals in Ghana is probably not more than can be found in most westem developed countries', 58 or 'Lebanon does not have a culture of gay bashing per se',59 or there is 'no queer bashing' in Indonesia. 60 This level of generality was in marked contrast to the detail available in the IGLHRR packets, discussed below, which were not utilised at all in the Australian cases.

55 Forty-eight per cent of Australian cases used DFAT cables as a source of country information. Of these, 85 cases used DFAT evidence specific to sexuality, ie were about conditions for gay men (or rarely, lesbians) rather than on other more general issues. Later figures will be taken as a proportion of the sexuality centred evidence alone.

56 See Human Rights Watch, By Inoilation. Only: Australian Asylunt Policy (2002) 14 (10C) Human Rights Watch, online at <http:/ www.hrw.org/asia/australia.php> at 19 December 2002.

57 See, eg, 'advice from academics and a health care professional (who is gay)' RRT Reference V97/06802 (Unreported, Wood, 30 September 1997). The decision-maker expressiy held that the applicant's submissions on the 'issues of illegality of homosexuality and the mistreatment of gays in the military' were insufficient to 'xebut the information contained in the documents, about the absence of a culture of "gay bashing per se", in Lebanese society.' Ibid.

58 In RRT. Reference N98/24600 (Unreported, Russell, 26 November, 1998).

59 In RRT Reference N95/10132 (Unreported, Griffin, 16 Seplember 1997) and RRT Reference N95/09483 (Unreported, Mathlin, 26 November 1997)

60 RRT Reference N97/15062 (Unreported, Short, 17 November 1997); RRT Reference V97/07412 (Unueported, Haig, 24 Decenber 1997) and RRT Reference N98/27139 (Unreported, Witton, 8 October 1998). 
The DFAT evidence, when it was on the question of country conditions specific to sexuality, was almost universally negative to the applicant's case. As such, it appeared that DFAT country information played a role in the high level of negative outcomes for asylum seekers in Australia as compared to Canada. When DFAT evidence on sexuality was accepted, 6189 per cent of applicants were unsuccessful. ${ }^{62}$ On the rare occasions when DFAT evidence on sexuality was rejected, the numbers of successfui applicants actually exceeded those who were unsuccessful. ${ }^{63}$ Where DFAT evidence was at odds with country information supplied by other sources, such as NGOs, the Tribunal tended to prefer the evidence of DFAT. ${ }^{64}$

DFAT evidence appears to have had an instrumental role in developing the 'Aiscretion requirement'. In numerous cases, the Tribunal considered whether an applicant could avoid a risk of persecution through being 'discreet'. The essence of the discretion requirement is that decision-makers find that applicants can and should avoid persecution by living closeted lives. It is noteworthy that DFAT evidence was the original source of the 'discretion' consideration ${ }^{65}$ and in the pool of cases where DFAT evidence on discretion was used, ${ }^{66} 84$ per cent of applicants failed. The importance of this discriminatory reasoning in the Australian jurisprudence is so significant that it features elsewhere in our analysis. ${ }^{67}$ The issue is under consideration in a case currently under appeal in which the High Court has reserved judgment 68 For the purposes of this argument it is sufficient to point out that this turn in reasoning seems to have been adopted directly from DFAT analysis of country conditions.

DFAT cables were also, on occasion, simply wrong. For instance, a cable on Lebanon stated that prosecutions for homosexual sex under the criminal law were 'rare', but this was directly contradicted by Lebanese press reports. ${ }^{69}$ In a 1995 case

61 As it was in 72 cases of 85 where it was considered.

62 The success rate of $x 1$ per cent is significantly lower even than the overall success rate of 22 per cent in Australia.

63 DFAT evidence on sexuality was not accepted in 13 cases; eight were successful and five were unsuccessful. This 62 per cent success rate is stumingly high in any aspect of the Australian case pool.

64 Despite noting the existence of Amnesty International evidence about prosecutions under customary courts, the RRT concluded that there was 'no independent evidence' of punishment by salish courts because it preferred DFAT's stance (which had criticised the Amnesty information): RRT Reference N94/04854 (Unueported, Woodward, 21 July 1998) and RRT Reference N95/09552 (Unreported, Woodward, 4 September 1998).

65 RRT Reference N93/00846 (Unreported, Fordham, 8 March 1994), discussed below, at text accompanying $\mathrm{nn} 72$ and 191.

6637 cases in total.

67 See Millbank, 'Tmagining Othemess'; Dauvergne and Millbank, 'Before the High Court', both aboven 2 .

68 5114/2002 and S 115/2002, special leave granted by the High Court 11 October 2002. The transcript of the Leave to Appeal is online at: <http:/ www austliiedu.au/au/other /hca / iranscripts/2002/S115/1.html> at 30 January 2003. The case, now renamed S 395/200 and $S 396 / 2002$, was heard on April 82002 and transcript of the hearing is available at <http://www.austii.edu.au/au/other/hca/transcripls/2002/S396/1.htmis at 15 April 2003.

69 RRT Reference N95/09584 (Unreported, Blair, 31 October 1996); RRT Reference N95/09483 (Unreported, Mathlin, 26 November 1997) and RRT. Reference N99/28440 (Unreported, Mathlin, 20 Jantary 2000). 
conceming an applicant from Bangladesh, the Tribunal noted that at first instance the delegate had relied upon DFAT' advice to find both that, 'homosexuality was not illegal in Bangladesh and, according to reliable sources in the Bangladesh legal profession, nobody had ever been prosecuted for homosexuality. ${ }^{70}$ The RRT pointed out tersely that this information was 'inaccurate' as the Bangladesh criminal code proscribes 'carnal intercourse against the order of nature' and there was evidence of prosecutions of gay men under this provision. At times the information within a DFAT cable was clearly self-contradictory. For example, DFAT evidence on Nepal was that, 'homosexuals receive the same treatment from police as other citizens', but also stated that there were no open or known homosexuals in Nepal (which makes equal treatment rather difficult). ${ }^{71}$ Likewise a DI AT cable on the Philippines stated that homosexuality was not illegal and that the 'criminal law is silent on the subject of consenting same sex relations and there is little or no prosecution under the statutes'. ${ }^{72}$

At times, the DFAT cables also included conclusions of fact or law. Such conclusions were often speculative and sometimes bordered on the fanciful, such as a cable stating that gay men in Nigeria would face violence only if 'overt': 'We would expect such a person could face beatings from people opposed to their sexuality in much the same way as can happen in Australia'. ${ }^{73}$ Even more problematically, these statements were frequently adopted as authoritative in the RRT decisions. So, for example, a DFAT cable noted that there was widespread extortion of gay men in Lebanon, but concluded in a speculative fashion that this was not motivated by 'hatred of gays', but by greed. ${ }^{74}$ 'The Tribunal accepted that conclusion and held that widespread extortion was not evidence of persecution. The "Tribunal did not analyse the evidence further - for example as evincing a particularly vulnerability of the targeted group, or as evidence of a likely failure of state protection. There are numerous other examples of a single speculative line in a DFAT cable being used as the basis for comprehensive conclusions on a country situation. In a cable on Bangladesh, DFAT speculated that,

While public discussion endorsing homosexuality would not be well received by many Bangladeshis, the most likely response is one of embarrassment, rather than anything stronger. (CISNET-CX28051, 19 February 1998).

This statement was used as the basis for disbelieving claimant's evidence that they had experienced persecution such as harassment, bashings and condemnation from local religious groups. ${ }^{75}$ This single statement also became the basis for broad findings in several cases that, despite other evidence of extortion and bashings, there was no risk of persecution if the applicant was exposed as gay or was openly gay by choice,

70 RRT Reference N94/05400 (Unreported, Chan, 28 September 1995).

71 RRT Reference N97/14745 (Unreported, Hardy, 14 July 1998); RRT Reference N97/14489 (Unreported, Gutman, 23 July 1998) and RRI Reference N98/23955 (Unreported, Gutman, 24 September 1998).

72 RRT Reference V98/09602 (Unueported, Haig, 31 May 1999).

73 RRT Reference N98/21542 (Unreported, Zelinka, 25 August 1998) and RRT Reference. N98/22269 (Unureported, Mathin, 2 September 1998). The decision-makes again referred to this cable but omitted the 'like Australia' in RRT Reterence N98/21044 (Unreported, Zelinka, 17 November 1998).

74 RRT Reference N95/10132 (Unreported, Griffin, 16 September 1997).

75 See, eg, RRT Reference N99/28009 (Urreported, Smidt, 19 June 2000). 
because Bangladeshis would 'ignore' homosexuality. ${ }^{76}$ If anything, the decisions become increasingly confident and conclusive as time passed, so by 2002 the Tribunal held on the basis of the cable that,

I am not salisfied that he faces persecution by non-gays since country information shows that Bangladeshis will, if possible, choose to ignore rather than confront the existence of homosexuality in their society. ${ }^{77}$

While DFAT cables were produced in response to particular questions, the questions themselves were often not reproduced in the text of the decision, and so could therefore be taken out of context, or as supporting a broader proposition than originally intended. 'This issue will be dealt with in greater detail in the section below' on the selective use of evidence. The framing of the questions and responses was also important as it directed and frequently narrowed the scope of inquiry. For instance, many DFAT cables assumed a dichotomy between the enforcement of criminal laws 'or' tolerance. These two extremes were then used as a frame by the Tribunal, and a range of other factors (such as extra-legal persecution, or the considerable dangers involved in 'tolerated' options such as anonymous sex in parks) were not considered. Likewise DFAT cables directed the range of factors the Tribunal considered by suggesting ways in which sanctions might be evaded (for example if an applicant were discreet, or wealthy). ${ }^{78}$

As all of the DFAT cables for a particular country would be sourced on the RRT' electronic database (CISNET) there was considerable scope for choice as the cables were collated over the years. ${ }^{79}$ It is notable that DFAT cables on occasion contradicted each other, 80 and so decision-makers were able to pick and choose among cables in.

See ibid; RRT Reference N00/36301 (Unreported, Rosser, 24 December 2001).

RRT Reference N98/21362 (Unreported, Kelleghan, 28 March 2002).

78 For example, DFAT evidence that wealth 'cushions' discrimination was used in a Lebanon case, RRT Reference N97/19504 (Unreported, Zelinka, 28 September 1998) and a Jordan case, RRT Relerence N98/23813 (Unreported, Rosser, 8 Jantary 1999).

79 Such cables may not be accessible to applicants as the database is not public. The Office of the UNHCR notes that:

In some national procedures, decision-makers commonly make use of sources of information which are not available to a refugee applicant including reports from diplomatic missions or fellow governments, or even in some cases reports from security intelligence agencies. Administrative law principles of natural justice and fairness provide that an applicant normally be permitted to know what evidence is being relied upon to reach a decision. The use of internal reports by decisionmakers without providing the asylum applicant or his or her legal counsel disclosure of such information may actually prejudice an applicant, as they would be unable to refute the evidence or provide a full and informed explanation in case of perceived discrepancies.

Gorlick, above $n 1,5$.

80 See, eg, on Colombia: 'homosexuals are, at times, the target of [social cleansing] campaigns' DFAT Report 0152 10/5/99 cited in RRT Reference N98/21549 (Unreported, Kelleghan, 8 September 1999), versus 'as a group homosexuals do not appear to be deliberately targeted by police or other authorities for harassment' DFAT Cable CR1196 10/6/96 in RRT Reference N97/19649 (Unreported, Mcllhatton, 22 April 1999). On Lebanon: [i]f homosexuals are not officially tolerated, to my knowledge they do not suffer discrimination, ostracism, violence or death threats' DFAT Cable BI.500123 of 25 September 1995 at CISNET CX11474 in RRT Reference N98/22311 (Unreported, Zelinka, 22 September 1998), compared with: 'DFAT advises that they know of clains of violence against gays in 
compiling country evidence, with no indication in the text of the decision that any selective process was going on.

There are potentially two structural reasons why the Australian Tribunal has developed such an extensive reliance on the services of DFAT. The first is that this information is cheap and readily available, and can be easily targeted to a specific information request. Whereas sources such as well known human rights NGOs, the US State Department, or the international commercial press might not mention the specific situations of gay men and lesbians, DFAT cables do. Further, the information is brief and directive, unlike more detailed comprehensive sources such as the IGLHRC materials and, therefore, is easy to use. Tribunal members face high case loads and considerable pressure to produce reasons quickly, and may therefore more readily rely upon sources of evidence that are easily digested and straightforward. ${ }^{81}$ It should be noted however, that members of the Canadian Tribunal handle a caseload approximately twice as high as their Australian counterparts. 82

Second, in many cases this information is already in the file when it reaches the Tribunal, ${ }^{83}$ As the decision at first instance is made within a neighbouring govermmental department, there may be bureaucratic-cultural reasons for sharing information in this way. The Tribunal states that it is relying less and less on DFAT over time. ${ }^{84}$ This trend does not appear to be reflected in the decisions in our study. However, if the first instance reliance on DFAT continues, a change in Tribunal practice may be of little consequence.

\section{SPARTACUS: A QUESTION OF QUALITY}

There were a number of areas in which the quality of information used by the RRT was dubious or its application inappropriate. Spartacus is the principal example of this. The guide was used in 24 per cent of RRT cases and never in the Canadian Tribunal. Use of

the military, none of which has been proven at law. DFAT advised, on the basis of discussions with academics and a gay health care professional, that ... there is a "pattern of abuse/harassment by some elements of the armed forces of gays (both civilian and military)", largely motivated by blackmail. DFAT Cable BI3135 in RRT Reference N95/09483 (Unreported, Mathlin, 26 November 1997).

81 This is most clearly evidenced in the practice of repeating cotuntry information. In many cases conceming applicants from the same country, the entire section on country evidence was reproduced in full from one decision to the next over a period of months or even years. This was initially notable in cases concerning counties that were not generally accepted as persecutory regimes such as China and the Philippines but in recent years the routine use of 'slabs' of country information has extended to far more problematic countries such as Bangladesh and Tran. See discussion below $n 152$.

82 The Canadian Tribunal has approximately 177 decision-makers and expects to be faced with approximately 40,000 decisions. The Australian Tribunal has 55 decision-makers. It received 6545 applications in 2000-2001 and made 5969 decisions. See Refugee Rerver Tribunal Annual Report and Immigration and Refugee Board, 2002-2003 Estintates above n $49,5,24$. The number of Canadian decision-makers is expected to rise to 197 . These figures reflect the impact of Canada's 'expedited process' option, the role played by a hearing officer who prepares and presents evidence in the Camadian Tribunal and the fact that written reasons are only mandated in nega tive decisions.

83 Above n 50.

8. Ibid 
the guide as a source of country evidence was strongly associated with negative decisions: of the decisions where it was used, 90 per cent of applicants were unsuccessful. 85

Spartacus ${ }^{86}$ is a travel guide aimed at gay men. It contains a wealth of information about tourist venues, is illustrated with extensive advertising, and relies on a certain amount of reader input into the compilation of the material. While the 1995/96 edition is over 1000 pages long, when a small number of Western countries with lengthy listings are removed, the guide covers the remaining 150 countries in just 500 pages, giving information in four languages. ${ }^{87}$ Venues are coded in the book, with descriptors ranging from 'breakfast service', 'wheelchair' accessible' and 'major credit cards accepted' to 'leather and jeans', 'massage offered', and 'at your own risk: dangerous place with risk of personal attack or police activity.' While some venues are coded as 'gay and lesbian mixed crowd,' the guide is clearly aimed at men and contains no information about venues of specific interest to lesbians.

Spartacus is a travel guide, and it is not focused, nor would one expect it to be, on Inuman xights issues or legal issues. It contains information clearly aimed at foreigners, and does not purport to describe the conditions faced by locals who live in the countries in question. 88 Most decision-makers did not make informed use of the guide. It was, for example, used frequently as evidence of 'increased tolerance' and a 'flourishing gay scene' in Shanghai. Yet the 1995/96 edition covered all of China - in five languages, including a half page map of China - in only two pages. The Shanghai listing in fact included only a few outdoor cruising areas. 89

Spartacus was used as a source of law in 26 cases. More than half of the time the guide was used it was as a reference to the state of the criminal law. For example, in the case of a lesbian applicant from the Philippines, the Guide was cited as authority that 'homosexuality' is legal and the age of consent is 18.90 The guide book was treated

85 This 10 per cent success rate compared to an overall success rate of 22 per cent in the Austratian decisions.

86 Spartacus International Gay Gruide (24th ed, 1995). The RRT uses a number of editions of Spartacus, and we have compared with the specific edition where appropriate. The 24th edition is the one most commonly used in our data and thus we refer to it for general comparisons.

87 Tbid. Together the USA, UK, Netherlands, Germany, Spain, France and Australia occupy more than half of the gride. Approximately 20 per cent of page content is advertising.

88 The RRT did not appear to accept this very obvious limitation when it was pointed out. In a negative decision for a gay man from Pakistan, the Tribunal stated:

The Tribunal notes that the submission does not address the information read to and offered to the solicitor at the hearing from Sparticus International Gay Guide

95/96 on the laws regarding homosexuality and behaviour in Pakistan. In the hearing, the lawyer dismissed this information as applying only to visitors although the Tribunal pointed out that this was nowhere indicated in that Information RRT Reference V97/06971 (Unreported, Ford, I February 1999).

89 Spartacus, above n 86, 145. AIso note on file with the authors is the reasons of a munister's delegate from January 2002 rejecting the application of a gay man from China. The reasons state that there has been 'a shift in the govermment's position toward homosexuality' and cites as authority <www. gaychina.com>. This website, when visited (at 14 March 2003) featured 'Smooth \& Horny Asian Boys!' with pornographic photos, videos, stories, chat rooms and sex shows accessible for a fee, as well as a message board that is freely avatiable.

90 RRT Reference N97/13911 (Unreported, Blount, 10 December 1997). 
as similarly authoritative on the law in Ghana, 91 Bangladesh, 92 Nigeria, 93 Sri Lanka, 94 China, 95 and others. It does not seem to us to be unduly exacting to expect decisionmakers as a matter of course to rely upon primary sources on the state of the law.

Spartacus was also on occasion used to counter other sources which gave a more detailed and legally focused account. ${ }^{96}$ For example, in one Costa Rican claim the Tribunal used Spartacus to counter information from Amnesty International and the Third Pink Book:

The Tribunal notes that although The Third Pink Book published in 1993 states that police raids are irregularly reported in San Jose, a laler gay guide Spartacus, says nothing about such raids and indicates that Costa Rican society mostly tolerates gays. ${ }^{97}$

This conclusion is drawn from the single statement: 'In spite of the influence of the Catholic church, society mostly tolerates gays. ${ }^{198}$ Most importantly, it ignores the information found two pages later that, '[t]he police regularly carry out raids at the following cruising areas! 99 The guide was similarly used to counter information from the Third Pink Book in assessing claims from Ghana. 100 Unlike Spartacus, the Third Pink Book does actually claim to document the social and legal situation of the countries that it covers. ${ }^{101}$

While Spartacus provides lists of venues that may be of interest to tourists, its use by the Tribunal as a legal authority is inappropriate given the avajlability of other sources. The lengthy argument for better use of the Guide presented by one member ${ }^{102}$ is

91 RRT Reference N98/24600 (Unreported, Russell, 26 November 1998).

92 RRT Reference N95/10037 (Unreported, Hunt, 25 February 1997).

93 RRT Reference N98/21542 (Unyeported, Zelinka, 25 August 1998).

94. RRT Reference V98/08356 (Unreported, Hudson, 28 October 1998).

95 RRT Reference N99/27818 (Unreported, Kelleghan, 29 June 1999).

96 RRT Reference N98/24600 (Unreported, Russell, 26 November 1998). Moreover, this case concerned a lesbian applicant; see discussion on gender-inappropriate use of Spartacus below, in the section entitled 'Gender-Blind Evidence: A Question of Relevance'.

97 RRT Reference N98/20912 (Unreported, Cristoffanini, 3 February 1999). The same thing occurred in a case concerning a lesbian from Ghana, where the Tribunal relied upon Spartacus in preference to the Third Pink Book (the latter stating that, in Ghana, homosexual behaviour is illegal ... In 1992, reports reached us of torture and imprisonment of gay men.'). Not only was Spactacus used in preference to this information, it was also relied upon by the Tribunal in this case as a souxce of law, stating that 'Spartacus, the gay travel guide published in 1998 says "In Ghana there are no laws prohibiting homosexualily."" RRT Reference N98/24600 (Unreported, Russell, 26 November 1998).

98 Spartacus Guide, above n 86, 153, and cited verbatim earlier in the decision.

99 Ibid 155, punctuation in the original - furthermose, one of the areas listed is coded at your own risk.

100 RRT Reference N98/24600 (Unreported, Russell, 26 November 1998) and RRT Reference N98/24718 (Unreported, Russell, 19 March 1999).

101 Aart Hendriks el al (eds), The Third Pink Book: A Global View of Lesbian and Gay Liberation and Oppression (1993).

I02 RRT Reference N98/24186 (Unreported, Hardy, 28 January 2000), a successful claim by a gay man from Bangladesh. The Tribunal states:

The Tribunal finds the Spartacus Guide to be a quite comprehensive guide to respective levels of recognition, visibility and tolerance of homosexuals in a great many countries around the world. If one compares the UK or Denmark entry with that of Jamaica or the Cayman Islands, one may reasonably form the impression that there is a great difference in levels and forms of recognition, visibility and 
prestmably an attempt to call the attention of his colleagues to a more thoughtful use of the guide and falls short of asserting that Spartacus is an ideal source of independent: evidence about country conditions, The problem is therefore twofold; that Spartacus is used frequently despite its tenor and intended audience, and that it is often used incompletely, without averting to all the information it provides on a particular country or cruising area. Further, we consider below inappropriate gender-blind use of Spartacus in assessing claims by lesbians.

Both Spartacus and the use of DFAT evidence demonstrate problems with the types of independent evidence used by the RRT. While there are better and worse uses of both sources of evidence, even the best use of each presents significant problems. In addition to problems of which evidence is chosen, our study also showed problems of how evidence was used once it had been accepted by the Tribunal.

\section{INAPPROPRIATE USES OF EVIDENCE}

Even when a decision-maker has all the available evidence at her disposal, there remains the question of how that evidence is used. In a court setting, this is another question answered by relerence to rules of evidence - by issues of relevance and weight and associated considerations of probative and prejudicial value. The core

tolerance between the first two countries and the latter two. One may reasonably note that in Jamaica, say, the only places in which homosexuals may safely, if very discreetly, idenlify themselves are in private tourist-oriented establishments, not easily patronised, for reasons of cost and perhaps reputation, by members of the local population. One may reasonably form the impression that an entry in the Guide for a country that only includes little or nothing more than a short list of 'cruising' Iocations, say, in parks, remote beaches, toilets and other sites designed or deemed suitable for fairly anonymous ablution or excretion, is an entry for a county where homosexuals have to be much more on their guard for one reason or another.

The Guide is quite arguably conceived and oriented for the consumption of Western gay travellers. Still, comparisons with Bangladesh are not invalid, not least of all because the Guide appears to essay towards comprehensiveness, as evidenced in its coverage of Thailand (20 pages), Viemam (1 page), Sri Lanka (2 pages), India (2 pages) and largely Muslim Indonesia (s pages). A survey of these countries supports the impression that the size of the countries' entries are not attributable to the respective countries' wealth or location along popular tourist trails, but, rather, to the extent to which taboos against homosexuality have either disappeared or were non-existent in the first place. Bangladesh, meanwhile, evidently maintains what may well be argued to be a statu tory justification for continued discrimination against homosexuals and ill will towards them.

.... However, it seems reasonable to form the view that if a country's only gay meeting places are anonymous 'pick-up' sites, there may be some form of pressure within society that forces homosexuals to deny their existence and identity to an extent not similarly or so thoroughgoingly enacted upon heterosexuals. Evidence to the effect that homosexuals in Bangladesh use public facilities like toilets instead of private accommodation like homes and apartments, or bars with names like Why Not, should not found the conclusion that homosexuals are comfortable Gatemising in public places, let alone that, this is indicative of a substantial degree of indifference to them as a class. The seemingly ironic expectation of being able to maintain anonymity in what is after all a public toilet coupled with the equally ironic anticipation of meeting someone with common purpose $\mathrm{m}$ such places, would appear, from much of the evidence submitted by the Applicants, to have nothing to do with a lack of concern about being detected. 
principle in this area is that all relevant evidence is admissible. ${ }^{103}$ The concept of relevance is treated as a matter of logic rather than of legal formulae: evidence is relevant if it tends to prove a fact that is in issue. ${ }^{104}$ Evidence is to be excluded if it is irrelevant, insufficiently relevant, or if its probative value is outweighed by its probable prejudicial effect. ${ }^{105}$ While the removal of technical rules of evidence for the refugee tribunal frees the Tribunal from formal considerations of relevance, the objective of the provision was presumably not to encourage the use of irrelevant or insufficiently relevant material - especially given the logical rather than technical underpinning of the rule.

A similar argument is applicable to the question of weighing evidence. The weight of evidence is a question of fact. To some extent weight may affect admissibility, and it may also be related to the degree of relevancy of the matter under consideration. 106 The tendency of contemporary law is to admit all relevant evidence but to then weigh it carefully. There is Jittle in the way of technicality to this aspect of the law of evidence. The importance of weighing evidence is instead left to the province of logic and prudence, neither of which are removed by the Migration Act. Evidence that is admitted despite low relevance or questionable reliability ought presumably to be dealt with in the process of weighing competing sources of proof. Our assessment of the use of evidence in the RRT indicated problems which correspond with each of the core ideas guiding appropriate use of evidence; that is, relevance, probative value, and weight.

\section{GENDER-BLIND EVIDENCE: A QUESTION OF RELEVANCE}

The quality of country information on lesbians was universally poor in the Australian Tribunal. Country information about 'homosexuality' tutilised by the Australian Tribunal was in fact very often information solely about gay men, yet this was rarely acknowledged. Even where the Tribunal did acknowledge that it had no specific information on lesbians, it was often content to simply assume that the information on men was applicable. In many cases this evidence was demonstrably not the best evidence available, and was furthermore arguably irrelevant in logical and in administrative law terms. So for example, one decision stated:

The Tribunal notes that although the Spartacus Gay Guide and the International

Encyclopaedia of Sexuality only refer to gay men, the DFAT Cable was in response to a

more general question about discrimmation against male and female homosexuals in

103 Jolun Dyson Heydon, Cross on Evidence (6 Australian ed, 2000) 84. Heydon formulates the rule: 'All evidence which is sufficiently relevant to the issue before the court is admissible and all that is irrelevant; or insufficiently relevant, should be excluded.' This rule is encoded in the Evidence Act 1995 (Cth) s 56.

104 Ibid 84-86. See, also, Ron Delisle and Don Stuart, Euidence: Principles and Problents (6 ed, 2001) 106-110. Section 55(1) of the Evidence Act 1995 (Cth) states that evidence is relevant if it '... could rationally affect (directly or indirectly) the assessment of the probability of the existence of a fact in issue in the proceeding.

105 In the US, Federal Rules of Evidence, Rule 403 states:

Although relevant, evidence may be excluded if its probative value is substantially outweighed by the danger of untair prejudice, confusion of the issues, or misleading the jury, or by considerations of undue delay, waste of time, or needless presentation of cumulative evidence.

Hevdon, above n 102, 97. 
Ghana. In light of the generality of the questions put by DFAT, and since the nature of the answers is largely consistent with the information contamed in the Spartacus Gay Guide and the International Encyclopaedia, the Tribunal believes that it is reasonable to inler that the observations contained in these three sources would be equally applicable to gay men as well as lesbians and there is no evidence before the Tribunal that lesbians are treated differently in Ghana from gay men. 107

In fact the DFAT cable in question only referred to 'homosexuals' and stated, '[w]e have received no reports of imprisonment/torture of gay men'. ${ }^{108}$

The use of universalised information about gay men in claims brought by lesbians always worked to the disadvantage of the lesbian applicants. The use of Spartacus provides a useful case study as it was referred to as a source of country information in ten Australian cases concerning lesbian applicants. While the Tribunal referred to Spartacus as a 'guide for gay and lesbian travellers', ${ }^{109}$ the book itself is in fact subtitled 'international gay guide', refer's only to 'gay' travellers throughout the 1995/96 edition, and is filled with advertisements for male venues featuring nude or semi-nude men. There are no images of women, no mention of lesbian travellers specifically, and no venue coding for women-only or lesbian-specific venues. 110 Moreover, the book is clearly slanted towards venues where male-male sex might be found around the world - so although it lists gay-friendly accommodation and coffee shops, most listings typically focus on gay bars, cruising areas and porn cinemas.

In all of the ten lesbian cases where Spartacus was used, it was clearly inapplicable to country conditions for lesbians and intappropriate to the applicants' individual claims. In every one of the ten cases the lesbian applicant was unsuccessful. In each of these cases, Spartacus was referred to as evidence that there were support groups, ${ }^{11}$ a gay scene, a visible gay presence, decreased hostility towards gays and lesbians, or increased tolerance of lesbians and gay men. This evidence was expressly used to support a conclusion that there was not a likelihood of future persecution of the applicant. Yet when the guidebook was read closely, it was clear that none of the cited material was actually applicable to lesbians.

In three applications by lesbians from China in 1998 and 1999, the Tribunal quotes Spartacus:

107 RRT Reference N98/24600 (Unreported, Russell, 26 Novenber 1998). For a more detailed discussion see Millbank, 'Imagining Otherness', above $\mathrm{n} 2$.

Tbid.

109 RRT Reference N95/09552 (Unreported, Woodward, 4 September 1998).

110 For instance, although it contains many codes for rightclubs and other vemues (denoting older crowd, leather etc) and includes a code for 'gay and lesbian mixed crowd' (GLM), all other codes refer implicitly to gay men and the 1995/96 edition of the guide did not even ist a code indicating Iesbian venues.

211. In two cases concerning lesbian applicants from the Philippines in 1997 and 1998, spartacus is cited as 'confirming' that 'homosexual support groups are active in the Philippines'. In fact no support groups are listed in that edition of the guide, and of the 19 bars clubs and discos listed for Manilla only one of them was coded as catering to a mixed gay and lesbian. clientele. RRT Reference N97/13911 (Unreported, Blount, 10 December 1997) and RRT Reference N97/19718 (Unxeported, Rosser, 21 April 1998). Both cite 653 of the 1995/96 edition. 
The gradual process of liberalisation in China is nevertheless making itself felt lor homosexuals. Gay scenes are beginuing to emerge in Peking and Shanghai, and tolerance is increasing. 12

Yet the actual contents of the book indicate that listings of the 'gay scene' consist of one disco in Beijing which is coded as ' $g$ ' for gay male only, and a list of beats and cruising areas for Beijing and Shanghai. ${ }^{113}$ In one of the cases the applicant was from Shanghai and the Tribunal continued, quoting the introduction to Shanghai from the guide:

Nowadays the only major Chinese city with a visible gay presence is Shanghai. The harbour quarter, which dates back to colonial times, is called the Bund and is the most popular cruising area in Shanghai. Many gays meet there in the afternoon, and towards everning the paths are full of promenading couples. 114

On reading the entry, it was clear that the 'visible gay presence' was confined to a single cruising area - there are no listings for any other venue in the 1995/96 edition. ${ }^{115}$ It is implicit, although not stated, that the couples in question are male. ${ }^{116}$

112 RRT Reference N97/17155 (Unreported, White, 23 September 1998); RRT Reference V98/0949S (Unreported, Wood, 30 March 1999) and RRT Reference V98/09501 (Unteported, Wood, 31 March 1999) all use this quote from the opening couple of sentences from the 1998/99 edition. In the 1995/96 edition this is worded slightly differently: "The gradual reopening of China has also started to be noticed by gays. Slowly a gay scene seems to be emerging in Peking and Shanghai and gradually some people are becoming more tolerant', above $\mathrm{n} 86,144$.

113 In one of these cases, the Tribunal also refers to a gay sex/cruising internet site's reference to gay mens' bars and cruising spots as authority for the statement that Shanghai has a 'Visible gay community'; see RRT' Reference N99/27818 (Unreported, Kelleghan, 29 June 1999). Note also that the decision did not go on to record that the author of the quoted report went on to warn that it is illegal to take a same sex partner back to a hotel room and reconmended that, if caught, one pays whatever bribe is asked.

114 RRT Reference N97/17155 (Unxeported, White, 23 September 1998).

115 It is noteworthy that five months earlier, the Tribunal had refused protection to a gay man who had been arrested and bashed when he was caught cuddling his partner at just such a cruising area - on the basis that he was guilty of a public order offence and so was not being persecuted on the basis of his sexual orientation: see RRT Reference No N97/14768 (Unieported, Thomson, 29 April 1998). This decision was altimately upheld by the Full Federal Court: MIMA o Gui [1999] FCA 1496 (Heerey, Carr and Tamberlin IJ).

116 In a 1999, case from Bolivia, the Tribunal used Spartacus to rebut earlier evidence that 'the attitude to homosextuality in Bolivia was hostile and there was no visible social support for gay and lesbian rights', by referring to it as evidence that there were 'gay verues in four Bolivian cities'. As in the examples from China, a listing of a small number of ventes in the guide was used to support a very broad claim, and again, none of the venues listed were for women.

The Departmental decision noted that according to a 1993 source, homosexuality

was not illegal but that the atlitude to homosexuality in Bolivia was hostile and

there was no visible social support for gay and lesbian rights. However, nore recent

sources refer to gay venues in four Bolivian cities ('Bolivia' Spartacus International Gay Guide 98/99 Gmünder B 1998 pp 90-91).

RRT Reference N98/23425 (Unreported, O'Brien, 28 April 1999). The 1995/96 has four cities listed, occupying less than a page in total, all with bars marked as exclusively gay or straight but 'of interest' to gays, and cruising areas. There is rothing listed for lesbians. Likewise, 'Spartacus, the gay travel guide published in 1998, says "In Ghana there are no laws prohibiling homosexuality". The guide lists gay organisations in Accra and Nkawaw and a gay travel group in Accra. (Spartacus Intemational Gay Guide 98/99, Bruno 
A more obvious evidentiary error is found in a 1999 case from Colombia, where the Triburtal agajn used a listing of venues from Spartacus - all of which were coded as gay-only, including porn cinemas and bath houses, to claim that the lesbian applicants (a couple) were objectively safe from persecution. While there is no logical reason to think that any lesbian should know where to find a gay men's bath house, the Tribunal also cloubted the clajmants' credibility on the basis that they did not know of these venues. ${ }^{117}$

Perhaps the most dazzling example arose in a 1998 case, where, in a claim by a lesbian from a village in Lebanon, the Australian Tribunal held that:

Independent evidence shows that Beinut possesses a fair degree of gay activity despite the formal law against homosexual acts. Homosexual guides such as Spartacus $98 / 99$... and CrusingForSex.com on the Internet point to gay cruising areas, beaches and nightclubs in Beirut. This points to a greater degree of tolerance than that purportedly found by the applicant in her village. 118

The Tribunal held that the woman in this case was not in dangel of persecution, and could relocate within her country. ${ }^{119}$ Even a perfunctory look at the source of evidence used to support these findings shows them to be irrelevant. CrusingForSex.Com, an Intemet site with listings exclusively for male-male sex venues around the world,

Gmünder Verlag, p 515)': RRT Reference N98/24600 (Unreported, Russell, 26 November 1998). In 1995/96 the organisations listed are 'clubs' with only postal addresses and no sense of what: their purpose is; the bars are all coded as being for gay men only.

117 RRT Reference N98/21459 (Unreported, Kelleghan, 8 September 1999).

I also consider that the applicants could alleviate their troubles in Colombia by moving out of their family homes into a house of their own and pursuing a lesbian lifestyle independent of their families and cultivating new friends and support groups. They may do this in Medellin, their home city, where there are eight gay bars clubs, five gay discos, one gay restaurant, five cinemas and three gay baths and where a gay support group, Movimento de Liberacion Sexual, is based (see: Spartacus: Inlernational Gay Guide, '98/99, 27th edn, pub. Bruno Gmunder Verlag GMBH, RRT Library). I am not entirely satisfied wilh the credibility of their claim not to have known about these venues and the organisation in Medellin given that they had moved around with other lesbians and owned to have gone to a gay club on a particular occasion; perhaps they had not known about all the tacilities available to them. I am confident that they would be able to find out more about these facilities without great difficulty and to avail themselves of the assistance offered by formal and informal support groups.

118 RRT Reference N97/18897 (Unreported, Kelleghan, I3 November 1998). Other evidence used in this case to determine that Beirut was cosmopolitan and therefore safe was even. more spurious:

I am of the opinion that she will be able to live in Beirut as a lesbian without undue interference if she adopts a discreet lifestyle. .... Beirut, with its sophisticated lifestyle (see eg: John McLauchin's article, Eyes On Beirut, through American Express on the Internet, updated on September 1998: 'Beirat reputedly has the word's highest per capita consumption of both cigars and silicone .... Now, as gilded young exiles flood back [after the civil war' the city's nightlife has come alive again.') would offer her freedom from the eyes of her family and in-laws, with their conservative localised village power-base.

119 If I were nevertheless to accept her evidence as being credible, I find that she would be able to relocate to Beirut and adopt a reasonably discreet lesbian lifestyle without the familial and village community harassment she had encountered previously.' RRT Reference N97/18897 (Unreported, Kelleghan, 13 November 1998). 
listed a single pornographic theatre in Lebanon 120 while Spartacus listed a single porn cinema, two saunas and selection of beats. ${ }^{121}$ What this has to offer a lesbian only the RRT can explain, yet if was expressly used to discredit the applicant's case and to find that she did not face a real chance of future persecution.

Contrasting the two Australian decisions concerning Iranian lesbians gives a clear sense of how directly gender-blind use of country information affected outcomes. In the first case, which was unsuccessful, the Tribunal used no evidence specific to the situation of lesbians in Iran. The decision did not comment about the status of women in the country, nor on how this status might affect lesbians' claims to protection from the state. DFAT country information indicating that there were 'health clubs' for gay men in Tehran was used to find that 'discreet' relationships are tolerated and lesbians are not in danger of persecution. ${ }^{1.22}$ All of the information on 'tolerance' of homosexuality in Iran, dubious though it was generally, was transparently about men. In contrast, in the second case, decided seven months later, the applicant was successful. In that case, the Tribunal looked at the status of lesbianism specifically and accepted that gender-specific country information was important. The case used Documentation, Information and Research Branch ('DIRB's') Human Rights Brief: Women in the Islanic Republic of Iran and Amnesty's Human Rights are Women's Right as key resources documenting that women had been put to death for being lesbians and that they continued to be at risk of being killed, ${ }^{123}$ All of this information was available to the Tribunal at the time the first case was decided, but none of it was used.

The use of gender inappropriate evidence in the RRT was vely widespread. ${ }^{124}$ Such evidentiary practices demonstrably contributed to the dramatically low success rate a mere seven per cent - for lesbian applicants in the Tribunal.

\section{MISREPRESENTATION OF EVIDENCE: PREJUDICIAL NOT PROBATIVE}

\section{The Office of the UNHCR in a recent working paper urges that:}

In assessing the evidence presented, which is of key importance in assessing an applicant's credibility, the decision-maker must consider all of the evidence, both oral and documentary. Furthermore, the evidence must be assessed as a whole and not just in parts in isolation from the rest of the evidence 125

It was disturbing that in a number of cases, the Australian Tribunal selectively used sources of information in such a way as to misrepresent them or present a misleading picture of the totality of available evidence. In several cases, tribunal members quoted sources about the existence of clubs or cruising locations as evidence of a 'thriving' or

120 At 10 October 2001.

121 "The 1995/96 edition of the guide lists one pornographic cinema, two saunas, a beach and seven cruising locales: see Spartacus Intemational Gay Gutide (24th ed, 1995) 557.

122 RRT Reference N98/23328 (Unreported, Hoysted, 27 November 1998).

123 Research Directorate Documentation, Information and Research Branch Immigration and Refugee Board Ottowa, Human Rights Brief: Wontert in the Islamic Republic of Irath (1994) and Aumesty International. Human Rights are Wonten's Right Persecution on grounds of sexual orientation (1995): RRT Reference N98/22363 (Unreported, Morris, 9 June 1999).

124. For a very rare contrast, see extensive, detailed and thoughtful use of gendered evidence in a case concerning a lesbian applicant from India: RRT Reference N98/23844 (Unreported, Layton, 29 August 2000).

125 Gorlick, above $\mathrm{I}, 6$ (emphasis in original). 
'visible' gay scene to disprove an objective likelihood of persecution. ${ }^{126}$ On contparison with the original source material, it was clear that the decision-maker had seen, but chosen not to record, accompanying warnings that such venues were dangerous or commonly subject to police harassment. ${ }^{127}$

In a series of decisions regarding claimants from China, the Tribunal referred to a DFAT cable from 1997 which stated that, '[t]here is a sizeable gay community in Shanghai, with known meeting places'. In only one case did the Tribunal print the full response from DFAT which continued:

Shanghai's population and the large foreign presence makes it easier for homosexuals to get together. That said, it also makes it easier for the public security bureau (PSB) to identify and harass homosexuals. Harassment can include arrest, temporary detainment, physical violence and demands for bribery (see below)

(b) There is still widespread social prejudice against homosexuality which would make it extremely difficult for gay couples to live together openly. It is possible that a more discreet arrangement might be tolerated.

The cable answered 'yes' to questions about police raids of gay venues ( $\mathrm{c}$ and $\mathrm{d}$ ) and continued,

(e) Crackdown on drugs and other criminal activities have been given as the reason for police harassment of homosexuals. Homosexuality per se is not a crime. We understand that some of those arrested in crackdowns in November 1996 and April 1997 were released after paying large sums to the PSB..$^{128}$

In numerous cases on China only part of the above cable was quoted. ${ }^{129}$ So, for example it appeared as:

DFAT commented in 1997 that there was a sizeable gay community in Shanghai and that there are known meeting places for homosexuals. Social prejudices against homosexuality still persist and that homosexuals could still be subjected to harassment. (DFAT SH642, 30 July 1997, CX25265). .30

126 RRT Reference N97/18897 (Unreported, Kelleghan, 13 November 1998), discussed above n 116, using Spartacus.

127 RRT Reference N97/78897 (Unzeported, Kelleghan, 13 November 1998). All of these sites are coded as, 'At your own risk. Dangerous place with risk of personal atlack and police activity'. In another case, the RRT quotes Spartacus 1995/96 651 saying, 'homosexuality is allowed on the Philippines and the age of consent is 18 ' and omits the following: 'presently we have disagreeing information. In the past, we were informed that situation for gays in the Philippines was not the rosiest because when the police were fighting against sex tourism and child prostitution they closed down gay establishments in the process'. RRT Reference N97/13911 (Unreported, Blount, 10 December 1997).

128 RRT Reference V98/09564 (Unueported, Vrachnas, 4 May 1999).

129 For example, RRT Reference V98/08938 (Unreported, Kissane, 2 November 1998) does include the first quote but omits the reference to police raids and the second quote; RRT Reference N97/19670 (Unreported, Holmes, 4 September 1998); RRT Reference N99/27818 (Cnreported, Kelleghan, 29 June 1999); RRT Reference N99/26435 (Unreported, Hoysted, 31 May 1999); RRT Reference N98/25578 (Unteported, O'Brien, 2 March 1999); RRT Reference N97/19671 (Unmeported, Kelleghan, 25 January 1999) and RRT Reference N97/20446 (Crnreported, Zelinka, 11 March 1999) paraphrase elements.

130 RRT Reference N98/26197 (Unreported, Gutman, 11 May 1999); RRT Reference N98/21640 (Unreported, Klintworth, 21 December 1998); RRT Reference N98/21178 (Unreported, Klintworth, 4 Decenber 1998) and RRT Reference N98/21639 (Unreported, Klintworth, 21 December 1998). 
Several of these decisions held that there was little or no likelihood of arrest, although the cable itself documented that arrests had taken place. In some cases the cable was quoted only to support the proposition that there was a sizable gay population and that the likelihood of persecution was therefore objectively low. ${ }^{131}$

The same pattern of selective and misleading representation of the county evidence appeared in cases concerning Bangladesh. There, evidence of $\mathrm{Mr}$. Khan of the $\mathrm{Naz}$ Foundation in a fax from 1997 included information that there were very few gay identified men in Bangladesh, few or no cohabiting gay couples, that men who conform outwardly to social norms, 'most importantly by marrying and having children' can 'get away with male to male sex provided it is kept secret', and that harassment of men who had sex with men mostly took the form of extortion by hustlers and the local police but could also include being bashed. Mr Khan stated that he was not aware of any prosecutions nor of any significant harassment from fundamentalist Islamic groups. ${ }^{132}$ This evidence was repeatedly cited as standing only for the view that there were no prosecutions and no harassment from Islamic groups. ${ }^{133}$

Other material was either misquoted or misrepresented. For example a source quoting a view that '[g]ay organisations in the country are of a pure social character' was used as evidence for the proposition that 'homosexual support groups are active in the Philippines. ${ }^{134} \mathrm{In}$ fact the original source stood for the opposite; that they were 'pure' social groups that did not engage in any political or organised public activities. The 'pure' social meaning is made clear' when the original source is examined: it does not in fact list any political or support groups. ${ }^{135}$

131 See eg, RRT Reference N97/20090 (Unreported, Short, \& March 1999); RRT Reference N97/14768 (Unreported, Thomson, 29 Apri! 1998).

132 See RRT Reference N99/28009 (Unreported, Smidi, 19 June 2000) repeated verbatim in RRT Reference N00/36301 (Unreported, Rosser, 24 December 2001)

133 See eg, RRT Reference N98/21005 (Urreported, Thomson, 25 May 2000); RRT Rererence N95/09552 (Unreported, Woodward, 4 September 1998); RRT Reference N98/20994 (Unreported, Rosser, 4 May 1998). In another case, il was cited only as evidence that there were places men could meet for sex: RRT Reference N98/21362 (Unreported, Kelleghan, 28 March 2002). Note that most of the country information utilised was around 5 years old. In direct contradiction to the Tribunal's repeated findings that Bangladesh is tolerant of male homosexual behavioux, more recent and more detailed evidence in a Naz Foundation study (of 124 Bangladeshi men who have sex with men) documented widespread violence and harassment. The study found that 64 per cent of respondents had faced police harassment, 48 per cent had been sexually assaulted by police and a further 65 per cent had been sexually assaulted by matastans (thugs, who are often involved with the police through bribery and other practices) with 71 per cent reporting other forms of harassment such as extortion and bashings, by mocstams: see Naz Foundation, 'Social Justice, Human Rights and MSM', Briefing Paper No 7, 2002, online at <http://www.nazfoundint.com/ home.htaul> Papers, Essays \& Reports, Briefing Papers (at 13 December 2002). See, also, the range of information collated in International Gay and Lesbian Human Rights Commission (IGLHRC), Current Lipdate Packet: Bangladesh, 2001.

134 RRT Reference N97/13911 (Unreported, Blount, 10 December 1997).

135 Spartacus, above n $85,651-3$. 
An early source for the view that 'discreet' homosexuals are safe in Iran was a 1996 report from the Swedish Embassy in Teluran ${ }^{136}$ In the next RRT case on Iran the applicant's adviser raised the fact that the report had been subject to very strident criticism in Sweden, not least of all because it based its conclusions in part upon the finding that 'homosexual diplomats posted to Iran have not had any trouble getting in touch with partners', ${ }^{337}$ Yet the report, excluding the comment on Swedish diplomats finding boyfriends, and excluding any reference to criticisms of the report in Sweden, continued to be cited in a number of cases that followed as though it were a sound and uncontested source of evidence. 138

In only one case did we find stch misrepresentations later corrected. A series of recent Australian decisions on Iran relied heavily upon the following information provided by DIRB:

Theoretically, homosexual behaviour is condemned by Islam, but in practice it is present, and has been in the past, for the most part tolerantly treated and frequently occurring in the countries where Islam predominates.' (quoting from Maarten Schild's 'Islam' in Schuritt and Sofer, Sexuality and Eroticisn Anongst Males in Moslem Societies.) IRDB; in IRN28636.E dated 11 February 1998.

This 'theory and practice' distinction was reproduced in full or relied upon in all Australian decisions on Iran over the period 2001-02, ${ }^{139}$ It is notable that the tribunal did not examine the original source material. When one of these decisions was appealed to the Federal Court, the Court noted that the use of this DIRB extract was in fact extremely misleading:

In respect of the passage from Schmitt and Sofer referred to by the Tribunal, it should be noted that in that extract Schild was commenting upon Islam in general, not Iran in particular. At pp. 185-186 of the text Schild went on to say that, in respect of Iran, the Ayatollah Khomeini had asserted that homosexuals had to be eliminated because they were parasites and corruptors of the nation by spreading the 'stain of wickedness'. Schild also stated that 'what occurred in Iran is certainly not typical of the attitude towards

The police and justice administration do not take active measures to investigate the existence of homosexuality, nor do they actively hunt homosexuals. All in all, the siluation in practice in Iran is drastically different from the impression conveyed by the Shari'a inspired Penal Code. According to information from usually very reliable sources, no homosexuals have been executed in fran for the last few years. In order to risk policiary sanctions, maltreatment or a short time in custody/jail, regardless of the fact that the penalty according to the law is death or whipping, a homosexual couple must: behave with great indiscretion, almost provocatively, in a public place.

Quoted in RRT Reference N98/23824 (Unreported, Morris, 31 July 1998).

137 RRT Reference N97/47733 (Unreported, Hoysted, 3 September 1998). The New Zealand Refugee Status Appeals Authority noted of this information, 'While we accept that such information may well have some relevance, we consider that the experiences of diplomats may not truly reflect the experiences of an Iranian citizen': RSAA Refugee Appeal No $71185 / 98$ (Unreported, Tremewan, Joe, 31 March 1999).

138 RRT Reference N98/24137 (Unreported, McIntosh, 13 October 1998); RRT Reference N98/23086 (Unreported, Rosser, \& July 1998); F o MIMA [1999] FCA 947 (Unreported, Burchett J, 9 July 1999); RRT Reference N98/25900 (Unxeported, Morris, 24 May 1999).

139 RRT Reference N01/37352 (Unreported, Witton, 24 April 2001); RRT Reference V01/12689 (Unreported, Kissane, 24 May 2001); RRT Reference N01/37891 (Unreported, Hardy, 16 October 2001); RRT Reference No1/40131 (Unreported, Keher, 5 November 2001), 
homosexuality in the whole spectrum of Islamic countries,' thereby indicating that the situalion for homosexuals in Iran was much more dangerous than in other Islamic countries. In the same text (at pp.67-69) it was stated that 100-200 homosexuals had been executed in Iran between 1981 and 1982.140

In all of the cases where selective presentation of the evidence took place, a fair assessment of the totality of the source material did not demonstrate, as the decisionmaker had held, an undikelihood of persecution. Indeed it is arguable that some of the country information quoted in full stood for exactly the opposite, that persecution was possible or likely. ${ }^{141}$

\section{Failure to Weigh Competing Sources of Evidence}

More commonly, the Australian Tribunal selected among different sources of evidence and referred to only some of them, without acknowledging either what sources were omitted or on what basis the chosen sources were to be preferred.

When we examined together all of the cases concerning applicants from Lebanon, there was a very sharp division between the successful and unsuccessful cases, with completely diflerent evidence relied upon in each group. In three of the negative cases, the Tribunal relied upon a DFAT cable as evidence that there was not a persecutory enviromment, ${ }^{142}$ yet none of the four positive cases mentioned this cable. ${ }^{143}$ Conversely, three of the four positive Australian decisions cited a 1987 statement by the Lebanese Embassy that 'homosexuality is not accepted in Lebanon', 144 but this evidence was not referred to any where in any of the four negative cases.

The same pattern of selective usage of evidence was also apparent in cases concerning Iran. An expert opinion provided by Chris Puplick in 1994, for instance, was quoted extensively in all of the positive decisions, ${ }^{145}$ and not referred to at all in

140 W133/01A o MIMA [2002] FCA 395, (Unueported, Lee J, 5 April 2002) [18] (emphasis added).

141 Note that Luke Hardy makes this point about lists of beats: RRT Reference N98/24186 (Unreported, Hardy, 31 January 2000). See above n 102.

142 A DFAT cable quoting an unnamed 'highly-reliable lawyer' who alleged that whilo homosexuals were technically 'not tolerated', 'to my knowledge they do not suffer discrimination, ostracism, violence or death threats' was relied upon in RRT Reference N98/22311 (Unreported, Zelinka, 22 September 1998); RRT Reference N97/19504 (Unreported, Zelinka, 28 September 1998) and RRT Reference N97/18897 (Unreported, Kelleghan, 13 November 1998).

143 RRT Reference N9406450 (Unreported, Fergus, 26 July 1996); RRT Reference N95/09584 (Unreported, Blair, 31 October 1996); RRT Reference N95/09483 (Unreported, Mathlin, 26 November 1997); RRT Reference N99/28440 (Unreported, Mathlin, 20 January 2000). Although three of these cases predate the negative ones, the cable was demonstrably available as it dates from 1995 and is on the RRT database: DFAT cable no. BI500123 of 25 Seplember 1995 CISNET CXI1474.

144t RRT Reference N95/09584. (Unreported, Blair, 3I October 1996); RRT Reference N95/09483 (Unueported, Mathlin, 26 November 1997); RRT Reference N99/28440 (Unreported, Mathlin, 20 January 2000). A positive Canadian case also refers to this source: Re LIJ] [1999] CRDD No 45, IRB References T94-07963 and T94-07973) (FTM transsexual and his mother).

145 RRT Reference N93/2240 (Lnreported, Fergus, 21 February 1994); RRT Reference N98/23824 (Unieported, Morris, 31 July 1998); RRT Reference N98/24137 (Unueported, McIntosl?, 13 October 1998); RRT Reference N98/25900 (Unreported, Morris, 24 May 1999). 
any of the negative decisions. ${ }^{146}$ A DFAT cable from 1996 on an 'anti-vice' campaign by the Basiji militia group was referred to in only one case, ${ }^{147}$ and not mentioned in any others, as was evidence of a public address by a leading Islamic cleric justifying putting homosexuals to death, 48 although such information was clearly relevant to whether or not there was a likelihood of persecution.

Sometimes the failure to refer to, and deal with, sources of evidence was even more blatant. In three of the positive decisions regarding applicants from Lebanon, the Tribunal contradicted DFAT evidence that prosecutions for homosexual sex were rare by reference to articles from the Beirut newspaper At Nahar dating from 1992-94 detailing numerous arrests of homosexual men. ${ }^{49}$ Astonishingly, none of the negative cases - even those that held prosecutions were unlikely by reference to the sanne DFAT source ${ }^{150}$ - took these news reports into account.

\section{Failure to read the evidence?}

One source of problems outlined above appears to be the use or overuse of the 'cut and paste' function by tribunal members in writing their decisions. It was quite common in decisions on the same country for large slabs of text on country conditions to be repeated verbatim over a period of years. ${ }^{151}$ The cut and paste approach to country information is particularly questionable when country conditions are alleged to have changed, or, as in some cases, where the applicant's own experience was in direct

146 RRT Reference N97/18050 (Unreporled, Berkley, 27 April 1998); RRT Reference N98/23086 (Unreported, Rosser, 8 July 1998); RRT Reference N98/23328 (Unreported, Hoysted, 27 November 1998); Fo MIMA [1999] FCA 947 (Unreported, Burchett J, 9 July 1999).

147 RRT Reference N98/23824 (Unreported, Morris, 31 July 1998). The applicant was successful.

148 RRT Relerence N98/22363 (Unteported, Morris, 9 June 1999).

149 In RRT Reference N95/09584 (Unreported, Blair, 31 Octoher 1996); RRT Relerence N95/09483 (Unreported, Mathlin, 26 November 1997); RRT Reference N99/28440 (Unueported, Mathlin, 20 January 2000).

150 RRT Reference N98/22311 (Unreported, Zelinka, 22 September 1998); RRT Reference N97/19504 (Unureported, Zelinka, 28 September 1998).

151 Over a dozen decisions concerning applicants from China used vintually identical country information over a period of four years from 1996 to 1999: RRT Reference V96/04281 (Unreporled, Billings, 27 June 1996) is identical to RRT Reference V96/04873 (Unreported, Smith, 29 May 1997) and RRT Reference N95/07373 (Unueported, Hardy, 27 June 1997). Then the information is updated somewhat and appears in: RRT Reference N98/21178 (Unreported, Klintworth, 4. December 1998); RRT Reference V98/09564 (Unreported, Vrachnas, 4 May 1999); RRT Reference N98/25853 \& N98/25980 (Unreported, Cristoffanini, 11. May 1999); RRT Reference N97/29241 (Unreported, Herron, 9 February 1999); RRT Reference N97/20090 (Unreported, Short, 8 March 1999); RRT Relerence N97/19671 (Unreported, Kelleghan, 25 Jantary 1999); RRT Reference N98/25578 (Unreported, O'Brien, 2 March 1999); RRT Reference N98/23196 (Unreported, Mclllhatton, 4 March 1999); RRT Reference N97/20446 (Unueported, Zelinka, 11 March 1999). In cases involving lesbian applicants from China, the country information used in RRT Reference N98/21639 (Unreported, Kliniworth, 21 December 1998) is repeated verbatim in RRT Reterence N98/21640 (Unreported, Klintworth, 21 December 1998). The same three page long slab of information is then cut and pasted (with acknowledgement) and used, unchanged in RRT Reference N98/26197 (Unreported, Gutman, 11 May 1999). For discussion see Millbank, 'Imagining Othermess', above n 2. 
contradiction to the evidence and no real attempt was made to reconcile them ${ }^{152}$ This practice almost certainly contributed to misquoting and selective usage of evidence, as original sources were not being consulted or checked for accuracy and reliance was placed instead on a secondary précis of the evidence from other decisions.

The reproduction of country information was not confined to cases by the same decision-maker; we noted several cases where different decision-makers used large sections of text that were identically worded or used very similar wording with minor editing or variation. ${ }^{153}$ This finding suggests an entrenched institutional practice whereby evidence is 'cut and pasted' into decisions. While this practice may reflect institutional imperatives, such as a high case load with a correspondingly short time in which to produce reasons, the practice of verbatim reproduction of evidence across decisions by different tribunal members must at least raise the real apprehension that some of the decision-makers in question have never at any prior time actually read the original evidence upon which they are basing their decisions.

It is also disturbing to note that some decision-makers appear to be reproducing slabs of their andlysis of the claims and country conditions from the decisions of other members on claims from the same country. ${ }^{154}$ The section of analysis is the core of the 'reasons for the decision' that the decision-maker is obligated to produce in writing under the Act ${ }^{155}$

152 In one decision on Iran the Tribunal held that gay men could live 'discreet' and therefore safe lives by visiting a local park for sex. The applicant's evidence was that he had been arrested by the Basiji in that very park, detained and bashed: RRT Reference NO1/37352 (Unreported, Witton, 24 April 2001). The Federal Court noted the manifest inconsistency of Gese findings in overtuming the decision: W133/01A v MIMA [2002] FCA 395 (Unreporled, Lee J, 5 April 2002). In another case the Tribunal held it was possible to conduct a lesbian relationship in Iran without coming to the attention of state or religious authorities. This was despite that fact that the basis of the applicant's claim was that when the relationship had broken up, her partner had publicly identified her as a lesbian, and that as a restlt she had begun receiving threats from the local community: RRT Reference N98/23328 (Unreported, Hoysted, 27 November 1998)

$\$ 53$ In the period 2000-02, four decisions on Iran are available, two of which fully reproduce country infornation without any re-wording by the Tribunal member: RRT Reference N01/40131 (Unreported, Keher, 5 November 2001) is a positive decision, identical country information appears in RRT Reference N01/37891. (Unreported, Hardy, 16 October 2001), a negative decision. The latter decision-maker includes an acknowledgement that he is 'quot[ing] here almost in full' from DIRB, but the former does not state this. In the same period, five decisions concerning applicants from Bangladesh appear, of which four reproduced country information. There were two identifiable boilerplates being used in these cases: RRT Reference N99/28400 (Unreported, Witton, 26 September 2001) was identical to RRT Reference N98/21005 (Unreported, Thomson, 25 May 2000). RRT Reference N00/36301 (Unreported, Rossex, 24 December 2001) used large sections of country evidence with minor re-phasing from RRT Reference N99/28009 (Unreported, Smidt, 19 June 2000). All four decisions on Bangladesh were negative.

154: Analysis that an applicant has been sexually active in the past and therefore is not disadvantaged by the 'discretion' requirement from RRT Reference N01/37352 (Unreported, Witton, 24 April 2001) appears to be very similar to the wording of Tribunal reasons quoted on appeal in Nezhadian. o MIMA [2001] FCA 1415 (Unreported, Finn J, 18 October 2001) [4].

155 Migration Act 1958 (Cth) s 368. 


\section{AN ALTERNATIVE APPROACH TO INDEPENDENT EVIDENCE}

Acknowledging the inherent difficulties of refugee decision-making, we considered and rejected - the argument that the RRT is doing the best it can with the information available. We did this by making two comparisons, with the Canadian Tribunal and with evidence available from the IGLIIRC.

A detailed qualitative comparison between the use of country information on Iran and Lebanon in the IRB and the RRT was particularly revealing. We chose Lebanon and Iran as key countries in part because both Canada and Australia decided cases from those countries, and in our pool Australia frequently rejected the applicant's claim on the basis of country information. In several cases, the RRT accepted the applicants' claims as credible but refused asylum on the basis that they did not face a likelihood of persecution in Lebanon or Iran because country conditions did not establish a persecutory enviromment. The Canadian Tribunal never rejected an applicant from Iran on the basis of country conditions alone 156 In the two IRB decisions on Lebanon, one claimant was rejected on the basis of country information. ${ }^{157}$

We also compared the country information used by the tribunals with that made available by the IGLHRC, a United States-based NGO formed in $1990 .{ }^{158}$ Since the early 1990 s one of the functions of the IGLHRC asylum program has been the compilation of large collections of continually updated country information on sexuality. ${ }^{159}$ Country packets contain press articles from local, regional and international sources, expert opinions, action alerts or updates from its own files, and relevant asylum decisions on the country in question, with no overarching commentary or summary. 160 Counlty information requests, or update requests, can be made to the IGLFRC using an online form or email. ${ }^{161}$

While Nicole LaViolette documents some early cases where the IRB regarded country information from lesbian and gay human rights groups as inherently biased

156 The IRB considered eight cases from lran - two failed on credibility grounds: Re $F V Y$ [1998] CRDD No 20 (QL), IRB Reference T97-01239 and Re TQB [1998] CRDD No 101 (QL). TRB Reference V97-01284.

157 ReWXV [1998] DSSR No 244 (QL), IRB Reference A98-00298.

158 The IGLHRC mission statement reads, [f]ounded in 1990, the International Gay and Lesbian Human Rights Commission (IGLI-TRC) is a non-governmental, non-profit organization that seeks to defend and advance the human rights of all peoples and communities subject to discrimination or abuse on the basis of sexual orientation, gender identity, or HJV status. IGLHRC responds to human rights violations in partnership with constituencies throughout the world through documentation, advocacy, and public education, with usage of supporting strategies such as coalition building, networking, and technical assistance.' See IGLRHC website <http://wwwiglhxc.org/> at 16 December 2002.

159 Prior to June 2002, this information covered approximately 20 countries. From June 2002 the scope of counties was reduced to: Brazil, Colombia, Egypt, India, Indonesia, Iran, Malaysia, Mexico, Nigeria, Pakistan, Ugarida, Ukraine - and three thematic packets on the Islamic world, tansgender issues, and lesbian issues respectively.

160 In this sense the packages are difficult to use as they do not attempt to provide a précis, but they also thereby avoid oversimplified or falsely coherent overviews such as are often found in DFAT cables.

161 See <http:/ / www iglhicoorg/asylum/rif.html> at 16 December 2002. 
and unreliable, ${ }^{162}$ it is clear that the IGLHRC is now highly respected by the Canadian Tribunal. The IGLFRC was referred to in one IRB case as a 'reliable and trustworthy' source of information. ${ }^{163}$ The TRB website lists the IGLFIRC asylum project as a resource and contains a link to the IGHLRC website. It was of considerable interest to us that, although the RRT claimed to have holdings of IGLHRC country information packets, ${ }^{164}$ they were not referred to in any of the Australian cases in our pool. ${ }^{165}$

Comparing the county information gathered by the IGLHRC and the RRT a number of contrasts became apparent. While the IGLHRC sources on Lebanon emphasised the impact of religious mores on law and society, the geo-political context of Lebanon, and its relationship to neighbouring, Islamic states, ${ }^{166}$ the RRT referred to materials that provided, in general, a far narrower picture and did not situate Lebanon in a regional context. 1.67 "The RRT tended to present a somewhat simplistic picture of the state, its internal politics and its role in sanctioning persecution. Most RRT decisions did not make clear the fact that all. religious communities in Lebanon maintain a strongly conservative stance on the issue of sexual orientation ${ }^{168}$ and were unclear about the issue of separation or collusion between church and state. ${ }^{169}$ RRT decisions did not mention the widespread presence of various militia groups in Lebanon, whereas the IGLHIRC country packet made clear the fact that these militias

162 LaViolette, 'Proving a Well-Founded Fear' above in 42. Note that the IRB undertook training in 1995 and 1996 on sexual orientation and refugee determination. The training focused on sources of documentary evidence, including listings of what sources are available from lesbian and gay NGOs, and a presentation on the difficulties involved in obtaining documentation of abuses. The training also included material on the appropriate and sensitive questioning of applicants about their sexuality when assessing credibility; La Violette, 'Sexual Orientation and the Refugee Determination Process' above n 42, 14.

163 Re EYW [2000] CRDD No 116 (QL), IRB Reference T98-10333.

164 Mantle, above n 51.

165 Although there were a handful of references to other IGLHRC resources, such as published books on particular countries, or 'Action Alerts' on specific issues, many of these were in fact quoted from another primary source, see eg, RRT Reference N98/24702 (Unreported, Layton, 16 February 2000).

166 For example, some sources made reference to Lebanon being a 'puppet state' of Syria, and noted that the official Syrian stance on homosexuality was extremely hostile. See Kamal Tayeb Fiazi, 'Expert Declaration [on conditions for lesbians, gay men, bisexuals, and transgenders living in Lebanon]', IGLHRC Current Lipdate Packet: Lebanon - Shatus of Sexual Minorities, 8 March 2001, 20.

167 See, eg, RRT Reference N94/06450 (Unreported, Fergus, 26 July 1996); RRT Reference N95/10132 (Unreported, Griffin, 16 September 1997); RRT Reference N98/22311 (Unreported, Zelinka, 22 September 1998); RRT Reference N97/19504 (Unreported, Zelinka, 28 September 1998) and RRT Reference N97/18897 (Unreported, Kelleghan, 13 November 1998),

168 The IGLHRC materials make clear that there is a 70/30 split between Muslims and Christians and religious identity is of crucial importance as a social identifier.

169 There was little understanding in the RRT of the way the Lebanese judicial system operates. It was not clearly pointed out that the criminal code is inspired by religious perspectives on behaviour, including crimes of morality (the category into which homosexuality falls). Although one positive decision, RRT Reference N95/09584 (Unreported, Blair, 31 October 1996), made reference to the 'morality police' (police des nceurs), the operation of this force, a branch of the Internal Security Forces, was completely ignored by the RRT in virtually all other instances. 
are often instrumental in attacking gay men and lesbians. Notably, an IRB decision on a female to male ('FTM') transsexual claimant provided a direct contrast to the RRT on these points. The IRB considered Lebanon in its regional context, made detailed reference to internal political divisions that impacted on the claimant (eg the conflict between opposing military groups) and also explored how religious identity politics affected the claimant's security. ${ }^{170}$

While the IGLHRC materials made clear that persecutory practices do exist in Lebanon, they did so by reference to a wide range of contexts, such as the schoot system, housing, employment, and family - in addition to violence at the hands of the police and paramilitary organisations. By contrast, the unsuccessful RRT decisions primarily focused upon formal legal sanctions and this framed all analysis of the nature of persecution in Lebanon. A formalistic focus on 'what's on the books' foreclosed a broader understanding of persecutory environments because evidence that prosecutions under the penal code were 'rare', ${ }^{71}$ lead to the conclusion that it was therefore 'safe' to return. ${ }^{72}$ It is notable that in three of the four positive RRT decisions, the Tribunal emphasised the interlocking forms of homophobia present in Lebanon, at all levels of state, church, society and family, in a manner that reflected the broaderbased approach present in the range of materials in the IGLHRC information packs. ${ }^{173}$

Decisions on Iran displayed an even heavier reliance upon evidence about formal legal sanctions and thejr enforceability. This gave a very partial and incomplete account of a persecutory environment. Other sources - such as speeches by clerical leaders calling for executions, or press reports of actual executions - were rarely utilised. ${ }^{174} \mathrm{~A}$ finding that the likelihood of persecution was low because criminal penalties were not trequently enforced was possible only through the failure to

170 Also, unlike the Australian cases (both positive and negative), the decision noted the fact that the claimants had been subject to opprobrium and hateful intimidation tactics within the Arab conmunity in Canada and extrapolated from this to say that claims of persecution. on return to Lebanon were reinforced by this fact

171 The DFAT evidence that prosecutions are 'rare' is contradicted by evidence in RRT' Reference N95/09584 (Unreported, Blair, 31 October 1996); RRT Reference N95/09483 (Unreported, Mathin, 26 November 1997); RRT Reference N99/28440 (Unreported, Mathitin, 20 January 2000) (in all of which the applicant succeeded) from the Beirut newspaper Al Nahar dating from 1992-94 detailing numerous arrests of homosexual men. This was the only use of cowntry of origin media that occurred in any of the RRT decisions - in contrast, the IGLHRC used a great deal of such media, especially the Beirut Daily Star (the leading English-language newspaper in Lebanon).

172 See RRT Reference N98/22377 (Unueported, Zelinka, 22 September 1998) and RRT Reference N97/19504 (Unreported, Zelinka, 28 September 1998). There was no understanding of the difficulties faced by gay and lesbian applicants in finding sources to back up their claims. Specifically, the Tribunal did not acknowledge the virtual impossibility of using one's family to assist in providing documentary evidence supporting the claim to asyltm - 'family members and often friends are terrified of the Lebanese authorities discovering that they have said anything negative about the Lebanese state or worse, about Syrial: Fiazi, above n 166.

173 RRT Reference N95/09584 (Unreported, Blair, 31 October 1996); RRT Reference N95/09483 (Unreported, Matllin, 26 November 1997); RRT Reference N99/28440 (Unreported, Mathlin, 20 January 2000). The fourth, RRT Reference N94/06450 (Unreported, Fergus, 26 July 1996), focused only on the fact that homosexuality was illegal under the penal code.

174 However, the one positive lesbian case in Australia does so: see above, $n 123$. 
examine the multitude of extra-legal punishments or the manifest unavailability of state protection to lesbian and gay citizens in that context. 'The Tribunal held that the 'discrepancy' between a death penalty being on the books and a general lack of evidence about specific executions demonstrated that, in theory, homosexuality is purishable by death, but in practice it is 'tolerated and not uncommon'. 175 In contrast, the IRB looked to the wider effect of such serious criminal sanctions in Iran. 176

There were instances in which IGLHRC material directly contradicted that used by the RRT. For example, three of the negative RRT decisions on claimants from Lebanon held that the applicant could take internal flight and so avoid persecution. 177 'The IGLHRC materials made it clear that internal flight was often not viable for lesbians and gay men. 178

In the sole case from Lebanon involving a lesbian applicant, the RRT did not use any evidence specific to lesbians and was content to refer to information about gay men as if it were equally applicable. The information in the IGLHRC packet, by contrast, suggests that homophobia in Lebanon is gender specific. It referred to culturally specific understandings of homosexuality as gender inappropriate behaviour, ${ }^{179}$ norms of feminine behaviour, and the role of 'honour'-related violence against women who are perceived as transgressive. ${ }^{180}$ Notably, in a Canadian decision concerning the

175. The independent evidence set out above ... suggests that there is a considerable difference between the explicit provisions of the Islamic Penal Code in relation to homosexuality and the situation in practice. The evidence indicates that the Iranian authorities do not actively seek out homosexuats and that the risk of prosecution for homosexuality is minimal as long as homosexual activities are carried out discreetly'. RRT Reference N98/23086 (Unreported, Rosser, 8 July 1998).

$176 \operatorname{Re}$ VAC [1998] CRDD No 161 (QL), IRB Reference V96-03502 noted that the IRB had before it certain pieces of information suggesting that, even though the death sentence was rare in Iran, the authorities can use the fact that homosexuality is illegal in order to abuse and humiliate gay and lesbian Iranians. Further, Re CXS [1995] CRDD No 134 (QL), IRB Reference T94-07573 and T95-02911 pointed out that the effect of the penal code's provisions was to 'set apart an identifiable class of individuals (homosexuals) and revile them because of their sexual orientation.'

177 RRT Reference N98/22317 (Unreported, Zelinka, 22 September 1998); RRT Reference N97/19504 (Unueported, Zelinka, 28 September 1998); RRT Reference N97/18897 (Unreported, Kelleghan, 13 November 1998).

175 The IGLHRC material states that intemal flight is 'urlikely if not impossible'because of the close-knit nature of Lebanese society, and the fact that people are easily identified and tracked down by members of their community of origin. Only RRT Reference N99/28440 (Unreported, Mathlin, 20 January 2000) made this point - drawing upon IRB material.

179 Homosexuality has a culturally-specific meaning in Lebanon, and is intimately connected to strongly-held betiefs about gender. Westem notions of sexual identity cannot be blindly pasted onto Lebanese society. Gay males tend to be conceived of as men 'wanting to be women' - an identily which is itself regarded as lowly. To be a homosexual male is to be reviled not only for having sex with men, but also for having been 'submissive' in the sex act. These understandings of homosexuality illustrate that it is not appropriate to substitute information specific to gay men in cases concenning lesbians. Fiazi, above n 166, 8-9.

180 Women who are perceived as lesbians or who are 'out' will likely 'be condemned by family, society and the security forces.' Thus, there is little prolection in being 'discreeli' - even being perceived as transgressing norms of feminine behaviour is potentially dangerous. Further, 'women who defy gender norms around sexual behaviour or identity are seen to bring shame on family honour.' Men have 'far-reaching power and contiol over their 
claim of a FTM transsexual, the IRB appeared to make extensive use of materials from the IGLIRRC country packet to deal thoroughly with the concept of 'honour killing' in response to sexually-transgressive fanily members. ${ }^{181}$

A number of RRT decisions relied upon country information that gay men were unlikely to be caught in Iran because it is very difficult to detect them.

Repressing 'homosexual' activities is rare for the security forces because of the difficulty

in identifying who is 'homosexual' and who is not since lranian men have very close physical contact (holding hands and kissing) which is socially accepted behaviour in Iran. 182

Such analysis reflects a very Western view that because a Westerner would see all such behaviour as gay, no Iranian would be able to detect a gay man through his behaviour. ${ }^{183}$ None of the IGLIIRC materials (many of which are written or provided by lranians living in the west) suggested that there was likely to be any protection for

women relatives' - as a consequence, these women can be 'victim[s] of violence within as well as outside the family'. Tbid 9 .

181 The IRB cases cite original sources rather than the IGLHRC. The sources cited are: 'The Trials and Tribulations of Lebanon's Young Gays', The Daily 5tar (Beirut), 26 October 1998 (Note 5); Decision Immigration Judge Elizabeth A Lamb, US Department of Justice Executive Office for Immigration Review, Immigration Court NY, May 5, 1997 (Note 7); and 'Iomosexuality in Lebanon', extracted from the Third Pink Book, above n 101 (Note 5): Re UIJ [1999] CRDD No 45, IRB References T94-07963 and T94-07973) (FTM transsexual and his mother). All of these sources are in the IGLHRC Country Packet: Lebanon \#2.

182 RRT Reference N98/23824 (Unueported, Morris, 31 July 1998). See also very similar comments by the RRT' in a Bangladesh case soon to be heard by the High Court: 'it is not unusual to see two men holding hands in public, as this is not seen as homosexual affection but merely as physical contact', RRT Reference N99/28009 (Unreported, Smidt, 19 June 2000).

183 Conversely, in another claim from Iran, the Tribunal refused to believe that the applicant was gay on the basis that the applicant did not conform to its understanding of gay men's interests and cultural reference points, due to the fact that the applicant could not identify 'an[y] art, literature, song lyrics or popular culture icons [that] spoke to him'. The Tribunal while 'not demanding that the Appilicant be a leading Gide scholar or even a Marilyn Monroe fan' or purporting to 'expect [that] all or any homosexual men in Iran ... take an interest, for example, in Oscar Wilde, or in Alexander the Greal, or in Naguib Mahfooz, or in Greco-Roman wrestling, or in the songs of Egypt's tragic muse Oum Khalsoum, let alone, say, in the alleged mystique of Bette Midler' or Madoma' was nonetheless 'surprised to observe a comprehensive inability on the Applicant's part to identify any kind of emotion-stirring or dignity-arousing phenomena in the world around him': quoted on appeal INA.AG o Minister for Intmigration [2002] FMCA 191 (Unreported, Raphael FM, 30 August 2002) [10]. While the decision was initially set aside in the Federal Magistrate's Court on the grounds of bias as revealing a 'closed mind' or 'pre-formed template into which the Tribunal considered all homosexuals males would fit', this conclusion on bias was overtumed on appeal to the Full Federal Court in MIMIA v SBAN [2002] FCAFC 431 (Unreported, Heerey, Moore and Kiefel J], IS December 2002). The Full Court reinstated the Tribunal decision as it held that there was no evidence of a 'template', stating at [65]: 'As a matter of common sense, this is a perfectly legitimate ... technique for an administrative decision-maker. To take an example removed from the ... present case, if an applicant claimed a fear of persecution on the grounds of being a Catholic, the RRT might test this assertion by enquiring as to the applicant's knowledge of matters of Catholic doctrine, ritual, traditional belief and the like. 
gay men provided by the publicly affectionate basis of typical Iranian male-male gestures. In a 2002 decision where similar information was utilised about Bangladesh, the decision-maker actually suggested that the applicant would be safer in the sending country than in Australia. ${ }^{184}$

Country information about culturally relative conceptions of gay male idenlity and behaviour was particularly ill-used in the RRT decisions. ${ }^{185}$ The RRT has interpreted evidence that male-male sexual contact in some cultures does not necessarily mean that a man is identified as gay in order to find that there was considerable room for homosexual applicants to safely pursue same-sex attractions, as long as they were careful to remain within the accepted norms of same-sex sexual activity. ${ }^{186}$ Such an interpretation arguably misreads an acceptable-unacceptable boundary which is differently located in the sending country to that of the receiving country as if it were in fact evidence of an area of greater acceptability in the sending country. Yet surely the essential element of each claim was that the applicant did not, or could not, conform to the heterosexual norm that his or her own culture imposed.187

The Australian Tribunal also repeatedly used country evidence about the repression of extra-marital heterosexual sexuality in Iran as a comparison point in holding that there was not a persecutory environment for lesbians and gay men in Iran. ${ }^{188}$ Some cases have gone so far as to suggest that gay men are safer than heterosexuals who are involved in unmarried sexual relationships. ${ }^{189}$ In not one of the

184. Given societal habits in Bangladesh he can show affection for other men in terms of holding hands with them or hugging them without causing outtage and risking harm. (In passing, I make the point that in cultures such as Australia's where such acts are automatically identified with homosexuality there is less public tolerance of them than is the case in Asian cultures such as Bangladesh's.)' RRT Reference N98/21362 (Unreported, Kelleghan, 28 March 2002).

185 For instance, decisions about lran sometimes cite the view that only the so-called 'passive' partner in anal sex is likely to be viewed as homosexual: see, eg, RRT Reference N97/14713 (Unreported, Hoysted, 3 September 1998). Such a conception might provide safety for one party to anal sex, but the danger of the other is not countenanced. In any case this interpretation is not borne out under the Iranian criminal provisions, which cover both parties as other cases have noted: see eg RR'T Reference N98/23086 (Unreported, Rosser, 8 July 1998).

186 So, for example, in a 2001 case concerning a gay man from Iran the Tribunal considered evidence of a continutum of male-male sexual activity and concluded that, '[t]here is nothing in the evidence before the Tribunal to indicate that a homosexual man in Iran is at risk of attracting the attention of the authorities nierely for being homosexual'; RRT Reference N01/37352 (Unreported, Witton, 24 April 2001) [3].

187 Cultural codes that delineate some acceptable 'phase' of male-male sexual activity, taken in conjunction with social mores that inscribe fixed gender roles and prioritise marriage, suggest to us a heightened concern with preserving female pre-matriage chastity rather than accepting male bi- or homosexuality. It is noteworthy that in none of the cases was there any country evidence concerning an acceptable phase of female-female sexual activity.

188 In RR' Reference N98/24137 (Unreported, McIntosh, 13 October 1998), the applicant pointed out that all sexual relationships (whether homosexual or heterosexual) between individuals ou side of marriage would be treated extremely harshly if revealed.

189 See, eg, RRT Reference N98/23086 (Unreported, Rosser, 8 July 1998), 'if anything, the independent evidence suggests that it is far easier for men to be publicly affectionate 
Iranian cases did the RRT acknowledge that the 'general' prohibition on extra-marital sexuality impacts particularly on lesbians and gay men since their relationships are necessarily conducted outside the bounds of marriage. ${ }^{190}$

The RRT relied heavily upon country information to establish the 'discretion' requirement - that the Iranian authorities would not pursue 'discreet' homosexuals and so all the applicant had to do was to live a secret, 'non-provocative' life and they would be safe. Yet none of the country sources elaborated upon what a clandestine lesbian or gay life would involve: what degree of secrecy and precaution would be 'normal' in such a context? Nor did the RRT detail what level of secrecy would provide a likelihood of safety. The IRB cases never based their decisions about likelihood of persecution upon a presumption of secrecy, even though they had very similar country information in front of them. ${ }^{191}$

A close comparison of country information on Lebanon and Iran in the RRT and IRB demonstrated significant differences in the two tribunals. The RRT repeatedly found that Iran and Lebanon were not persecutory environments for lesbians and gay men, while the IRB never did so on Iran and did so only once on Lebanon. In the decision-making process, the RRT showed a marked preference for simplified sources of evidence, did not situate claims well in their context - such as gender or region and often simplistically contrasted formal legal sanctions and 'tolerance' without examining the range of persecutory practices that fell in between. The evidence used by the RRT was often at odds with that used in the IRB and with that available to the public in the IGLIFRC country information packets. Given the significance of country information in determining the outcomes of refugee cases, it is strongly argued that greater effort should be made to access the most comprehensive information available.

toward each other in Iran than it is for a man and a woman.' See also RRT Reference No1/37352 (Unueported, Witton, 24 April 2001).

190 Likewise decisions on forced marriage or pressure to many in Bangladesh did not see this as in any way connected to sexual orientation. See, eg,

the Tribunal finds that such social and taditional pressure would be one that is dixected at all singte Bangladesh males (and females) many of whom will be pressured to enter into marriages, often arranged by their parents, that are not to their Iiking. The Tribunal linds that any such pressure, even if it wore some significant detiment or disadvantage of sufficient magnitude as to constitute persecution for the purposes of the Convention, would not be being caused for reason of the applicant's homosexuality. Rather it represents general pressure exerted upon all single adults in that society.

RRT Reference N99/28400 (Unreported, Witton, 26 September 2001). See also MMMv MIMA [1998] 1664 FCA (Unreported, Madgwick J, 22 December 1999), and contra RRT Reference N98/24186 (Unmeported, Hardy, 31 January 2000).

191 Re VAC [1998] CRDD No 161. (QL), IRB Reference V96-03502 explicity renounced this argument, saying that it was not 'reasonable' to demand that the applicant be clandestine: Why should he have to live a discreet life as a homosextal in any country, if homosexualily and his right to be a homosexual is somelhing that is a basic fundamental humarn right for him?' Similarly, Re IPD [1997] CRDD No 296 (QL), IRB Reference T9702485 held that information stating that discreet homosexuals would be tolerated in Iran was not a satisfactory argument about their safety given that all sources agreed that opert displays of homosexuality would not be permitted. 


\section{CONCLUSIONS AND RECOMMENDATIONS}

Canada and Australia have very similar laws and processes for refugee determination. Both cotuntries have been adjudicating refugee claims based upon sexual orientation since the early 1990s. Yet the two countries manifest very differenl results, with Canada more than twice as likely to accept refugee applicants on the basis of sexual orientation than Australia. The greater overall success rates of applicants in Canada and the hugely greater success rate of lesbian applicants in Canada, compared to Australia, can be explained in part by the extremely poor evidentiary practices of the Australian tribunal.

We suggest a number of areas in which the RRT could make changes to its current practice. These recommendations are grouped in the areas of availability of evidence, sources of evidence, and use of evidence. Many of these changes could be made at the level of administrative practice.

\section{A Availability of evidence}

\section{The RRT Cotntry Information database should be made publicly accessible}

This would bring the RRT's practice into line with IRB practice and would enhance the aim of having the fullest range of information available to all parties. It would relieve the burden of collecting counlry information from applicants and would also allow them to marshal evidence in advance of their hearing to counter any adverse country information.

\section{The introduction of Refugee Protection Officers as used in the IRB}

"The officers bring forward relevant country information to the tribunal member to assist them in making a decision. A Refugee Protection Officer would lessen the burden on tribunal members to gather evidence and contribute to the use of more upto-date and better quality evidence.

3 The RRT hearing itself should be subject to requirements of procedural faimess including a duty to inquire

While the applicant must be provided with specific adverse information, our study demonstrates that many claims are decided negatively on the basis of more general country information. An enhanced requirement of procedural faimess in conjunction with a duly to inquire of the applicant would mean that such information was more fully addressed in the hearing process. This is particularly important when it is noted that such 'findings of fact' on country conditions are virtually non-reviewable,

\section{Decisions of the RRT should be made publicly available}

Prior to June 1999, all RRT decisions were published. Since that time, the tribunal releases only decisions that are found by the Principal Member to be of 'particular interest'. The Principal Member also takes into account the degree of difficulty in removing identifying information from the decisions. ${ }^{192}$ The fact that a decision is, or

192 Migralion Act 1958 (Cti) 5431. 
is likely to be, under judicial review is not taken into account in determining whether the decision is of interest. ${ }^{193}$

At present only around 20 per cent of RRT decisions are released to the public. We have found a significant decline in the number of cases on sexual orientation available in recent years. ${ }^{194}$

Access to decisions is important both from a public interest point of view in examining the outcomes of the tribunal, and for the ability of other applicants to build their arguments. The RRT does not record figures for the number of applicants, or success and failure rates, based upon the Convention ground claimed by the asylum seeker. Nor does it release figures on gender. Tribunal figures are kept based upon cowntry of origin only. It is therefore only possible to identify trends and issues in the decisions of the tribunal both quantitatively and qualitatively by having access to the published reasons for decisions.

Moreover, as the RRT is increasingly a fortum of final jurisdiction, it is of even greater importance that its decisions be transparent and accountable.

\section{$B$ Sources of evidence}

1 The RRT should obtain and make use of evidence from organisations with specific expertise in human rights abuses based upon sexual orientation

Amnesty International has also recommended increased use of information that is specilically drawn from organisations that have expertise in sexual orientation and gender. 195 The country information packs compiled by the IGLITRC are easily accessible and comprehensive resources, yet they do not appear to be utilised by the RRT. These resources are used by the IRB and regarded by that Tribunal as credible and reliable sources of evidence.

\section{DFAT cables ought no longer be used as sources of country evidence}

These cables are low quality information. They are excessively general and are not verifiable by reference to the original source. They have been repeatedly misused to support broad conclusions. DFAT cables also raise an appearance of bias as they are sourced from a closely connected government department.

193 Communications with Kristian Bolwell, RRT, 8 November 2002 and 13 December 2002. Hence the Tribunal refused to release the decision currently on appeal to the High Court: $S 395 / 2002$ and $S 396 / 2002$, see above n 68 . In the period 2000-02, we located 11 Federal Court decisions, of which we were able to gain access to only two of the first instance decisions. This demonstrates that the Tribunal is releasing a fairly small proportion of its decisions, including those subject to judicial review.

194 In 1998 and 1999 for instance, we have 64 and 56 Tribural decisions, while in 2000 the number drops to 23; to 21 in 2001; to 14 in 2002.

195 Recommendation 7 , '[p]rotect refugees fleeing torture based on sexual identity' the following specific recuurement, '[w] hen assessing claims, country-specific information should be actively sought from LGBT, women's and other human rights organizations which document torture, ill-treatment and other abuses against LGBT people.' Amnesty International, Crimes of Hale, above n 5, 63 . 
3 The Spartacus International Gay Guide ought no longer be used as a source of country evidence

This is a low quality source of information withch was not intended to document country conditions and which has been repeatedly misused to support broad conclusions as to country conditions. If its use were continued at the very least it should never be used as a source of law, and when used should be far more carefully used - so that full information is cited, cross checked with actual listings and codes (including warnings), and used only on matters that it is specific to - such as the availability of sex venues for foreign men.

\section{Malce greater use of country infornation collected by the IRB}

This information is publicly available, accessible to applicants and often provides the original source material.

\section{Consider having RRT members specialize in 'sexuality' claims as they currently do} in 'country' claims

This would allow a greater specialisation of knowledge, particularly on country conditions. It would increase the likelihood of decision-makers becoming acquainted with original sources of evidence and thereby reduce the problematic and error-prone practice of decision-makers relying upon summaries of country information drawn from the decisions of other members.

\section{Use of evidence}

1 Provide training for RRT members specifically on the issue of evidence in claims based upon sexual orientation.

The aim of this training would be to assist members in eliciting and assessing evidence in an accurate non-discriminatory fashion. The IRB undertook such training in 1995. Amnesty International has recommended that such training be undertaken by all refugee decision-makers both at primary and appellate stages. 196 Such training could cover both independent evidence and evidence such as country information and also evidence drawn from the applicant him or herself, such as appropriate methods for questioning and assessing credibility.

Facing questions of credibility squarely could produce fairer outcomes. Our sense from several of the decisions was that decision-makers on occasion disbelieved the applicant's claim to be lesbian or gay, but were reluctant to make findings on their credibility. Instead they noted their disbelief, assumed for the purposes of the decision that the claimant was gay and went on to refuse the claim on the basis of a broader finding on the country conditions instead. This then 'lifted the bar' for later genuine claimants from the same country who were faced with a preconception that the country in question was not persecutory, even if their own evidence demonstrated otherwise.

196 Recommendation 7, '[t]raining should include how to eliminate bias in interviewing, documenting and accessing country-specific information, and should involve LGBT rights groups': íbid 62 . 


\section{Draw up guidelines on sexual orientation}

Such guidelines would complement, and could be used in conjunction with, appropriate guidelines for assessing refugee claims on the basis of gender-based persecttion. We also support a revision of the Australian Gender Guidelines to address the particular circumstances of lesbians, and an increased use of the Guidelines by the Tribunal. Amnesty International has also recommended drawing up such guidelines, in conjunction with training for decision-makers. ${ }^{197}$

\section{Reaffirm a commitnent to the principles of evidence}

The Tribunal should make use of the best evidence available and weigh that evidence in a transparent and accountable manner. "The selective usage of sources and selective editing of sources do not accord with these principles. The practice of cutting and pasting country information both from within a decision-maker's own earlier decisions and from those handed down by other decision-makers, without regard to the original sources contributes to manifest errors in the use of evidence and to improper weighting of evidence, It also raises an apprehension that the original evidence is not being read.

\section{Draw up guidelines on assessing relevance and weighing sources of evidence}

Such a guide could give factors to be considered when determining the relevance of evidence and weighing the relative reliability and authority of different sources of country information. Relevant factors include whether evidence is drawn from a primary or secondary source, if evidence is drawn from a secondary source whether the primary source is identifiable and whether secondary material can be cross checked for accuracy, the purpose of the source information, the funding and purpose of any organisation from which the information was produced, the intended audience of the information, the age of the information, and whether the information is genderspecific.

\section{Conclusion}

In the majority of asylum applications in Australia, the RRT is the ultimate decisionmaker. It is in the interests of justice as well as efficiency that its determinations be based upon high quality evidence and sound evidentiary practices. Our study demonstrates that this has not been the case in Australia to date. Many improvements could be undertaken at the level of administrative practice to ensure better quality decision-making through the use of the best available evidence as well as consistency and accuracy in its application. Our recommendations are achievable without legislative change. Many are achievable at no cost. Some would require an initial investment in professional development training, but would subsequently have no cost. We urge the Tribunal, to immediately begin a process for implenenting these recommendations, in the interests of fainess, Australian refugee law, and the international leadership role that Australia plays in developing refugee jurisprudence.

197 Recommendation $7{ }_{r}^{\prime}[\mathrm{g}$ ]udelines should be issued to immigration officials and others involved in the asylum process for the sensitive handling of claims based on sexual orientation': ibid. 